
H. \& M. BROCANDEL 2007. Chironomid responses (Insect: Diptera) to Younger Dryas and Holocene environmental changes in a river floodplain from northern France (St-Momelin, St-Omer basin). The Holocene 17: 333-349

\title{
Chironomid responses (Insect: Diptera) to Younger Dryas and Holocene environmental changes in a river floodplain from northern France (St-Momelin, St-Omer basin)
}

\author{
Emmanuel Gandouin, ${ }^{1 *}$ Philippe Ponel, ${ }^{1}$ Evelyne Franquet, ${ }^{1}$ \\ Brigitte Van Vliet-Lanoë, ${ }^{2}$ Valérie Andrieu-Ponel, ${ }^{1}$ David H. \\ Keen, ${ }^{3 \dagger}$ Jacques Brulhet ${ }^{4}$ and Marcel Brocandel ${ }^{4}$
}

('IMEP, UMR-6116/CNRS, Université Paul Cézanne, Europôle Méditerranéen de l'Arbois, Pavillon Villemin, BP 80, F-13545 Aix-en-Provence Cedex 04, France; ${ }^{2}$ PBDS, UMR-8110/CNRS, USTLille, F-59655 Villeneuve d'Ascq Cedex, France; ${ }^{3}$ IAA, University of Birmingham, Birmingham B15 2TT, UK; ${ }^{4}$ ANDRA, Service de Géologie et Géoprospective, Parc de la Croix Blanche, 1/7 rue Jean Monnet, F-92298 Châtenay-Malabry, France)

\begin{abstract}
Lateglacial to Holocene subfossil chironomids from the St-Omer basin at St-Momelin (northern France) were analysed. At the end of the Lateglacial, stratigraphic and chironomid sequences indicate a shallow, oligotrophic and slow-flowing freshwater stream, with abundant aquatic macrophytic vegetation. Cold-water adapted taxa indicate a cold climate. During the early Holocene, from about 9500 to 7700 conventional radiocarbon yr BP, climate improvement is marked by an increase in warm-water adapted taxa and a decrease in cold-water fauna. However, the cold-water fauna persist, probably because of both the instability and continentality of the climate. During the mid Holocene, from about 7700 to $6000 \mathrm{BP}$, the marine transgression strongly influenced the river's hydrological regime and consequently the chironomid assemblages. At that time, eutrophic, warm and shallow stagnant-water conditions occured throughout the basin. From 6000 to 3200 BP, the St-Momelin basin was subjected to a marine regression. Chironomids indicate a hydrological regime marked by an alternance of phases with either a dominance of rheophilous or limnophilous fauna. During this period, equivalent percentages of warm- and cold-adapted taxa may be explained by cold-water input in context of a temperate climate.
\end{abstract}

Key words: Palaeoecology, palaeoclimate, Holocene, marine transgression, hydrological regime, river floodplain, North Sea, Chironomidae, northern France.

\section{Introduction}

The analysis of subfossil chironomids has been used frequently in palaeoecological investigations of Quaternary lacustrine sediments as they are excellent indicators for Quaternary palaeoenvironments and palaeoclimates (Lowe and Walker, 1997). Like coleoptera (Elias, 1994), chironomids

*Author for correspondence (e-mail: e.gandouin@univ-cezanne.fr) respond rapidly to environmental change, as a result of their short lifespan and the dispersive capacity of winged adults. For example, chironomids that have been well preserved in lake sediments (Hofmann, 1986), provide valuable reconstructions of: (i) palaeotemperature (eg, Lotter et al., 1997; Brooks and Birks, 2000b); (ii) lake eutrophication and nutrients assessing (Lotter et al., 1998; Langdon et al., 2006); (iii) dissolved oxygen (Francis, 2001; Quinlan and Smol, 2001a) and; (iv) water-level changes (Hofmann, 1998; Korhola et al., 2000). However, chironomid analysis in fluvial systems is 
poorly developed, despite its potential for palaeoecological (Gandouin et al., 2005, 2006) and archaeological investigations (Ruiz et al., 2006) of floodplains. For example, Gandouin et al. (2006) have illustrated for the River Aa (northern France) that mid-Holocene hydrodynamic variations (potentially induced by climate change) can be reconstructed from subfossil chironomids. In addition, a middle pleniglacial sequence in the Dinkel Valley (The Netherlands), was studied by Ran (1990) with the aid of chironomid subfossils in association with pollen analyses. The chironomids provided valuable ecological information on the functioning of the Dinkel River, in particular, concerning the aquatic vegetation cover and the rate of water flow.

Based on a large data set consisting of 127 chironomid taxa and 991 sites situated in running water in Italy, Rossaro (1991) suggests that chironomid species can be sorted according to their optimum water temperature, from cold stenothermal species to warm water species. It is therefore probable that river chironomid subfossils can also provide thermal information concerning past water temperatures that may potentially relate to climate change.

Previous studies (Van der Woude and Roeleveld, 1985; Sommé et al., 1994) have identified thick early Weichselian, Lateglacial and Holocene sequences at Watten and St-Momelin in the St-Omer basin, northern France. The chronological depth of the sequences makes this subsiding area of the Flemish maritime plain an ideal place to analyse the functioning of the river system in connection with the variations in postglacial climate and sea-level rise. It also allows the investigation of land-ocean interactions in mid- and north-European latitudes.

In 2000 a multidisciplinary programme was launched (Gandouin, 2003) in order to reconstruct environment and climate change from the end of the Lateglacial to the mid Holocene. Thick sequences have been investigated through the analysis of multiple proxies, including sediment, pollen, molluscs, chironomids and coleoptera. The present paper focuses on the chironomid assemblage as other analyses are still in progress.

At a regional scale, the maritime plains from Great Britain, Belgium, The Netherlands and Germany are relatively well documented from pollen analysis (Mullenders et al., 1972; Munaut and Paulissen, 1973; Bohncke and Vandenberghe, 1991; Waller, 1994), geomorphology and chronostratigraphy (Plater et al., 2000; Streif, 2004), insects (Dinnin, 1997; Coope, 1998) and multiproxy investigations (Long et al., 1996, 1998; Preece and Bridgland, 1999; Berendsen and Stouthamer, 2000). Valuable data on climate (Zagwijn, 1994; Brooks and Birks, 2000a; Davis et al., 2003; Bedford et al., 2004) and the postglacial sea level rise (Pirazzoli, 1991; Preece, 1995; Shennan and Andrews, 2000) are also available for northern Europe. However, the French coasts of the English Channel and the North Sea remain underdocumented because the only existing continuous records are located in a few inland sites, such as in the Paris basin (Van Zeist and Van der Spoel-Walvius, 1980) and at Verrières in the Seine Valley (Limondin and Rousseau, 1991).

The aims of this paper are: (i) to produce a palaeoenvironmental reconstruction based on chironomid assemblage dynamics, (ii) to produce a preliminary water temperature range estimation, and (iii) to compare the St-Omer record with other contemporaneous climate reconstructions for NW Europe.

\section{Study site}

The site (Figure 1) has already been described by Van der Woude and Roeleveld (1985) and Gandouin et al. (2005). The
St-Omer basin (Pas-de-Calais region, northern France) is located downstream of the Aa river. The $560 \mathrm{~km}^{2}$ river catchment is predominantly located in a zone of subsidence (Mansy et al., 2003) on a chalk substratum that extends into Eocene clay in its lower part at the St-Omer basin (from Arques to Watten). This basin $\left(40 \mathrm{~km}^{2}\right)$ is situated close to the North Sea. A single narrow outlet (about $1 \mathrm{~km}$ wide near Watten) connects the large catchment basin and the maritime plain. The gradient of the river along the basin is gentle, amounting to only around $0.1 \mathrm{~m} / \mathrm{km}$. Because of its very low elevation $(2 \mathrm{~m}$ above sea level) the basin served as an estuary during the two major episodes of postglacial sea level rise; these were first described by Dubois (1924) and regionally named the Calais and Dunkerque transgressions, respectively. Subsequently, further subdivisions have been described that include more marine episodes within the North Sea basin: Calais I-IV and Dunkerque 0-III. The chronological position of each marine episode differs from one region to another according to complex glacio-hydro-eustatic readjustments and neotectonic processes (Denys and Baeteman, 1995; Lambeck, 1997; Waller and Long, 2003). A chronology for the Flemish-German plain is provided by Behre (2004) and a synthesis is given in Table 1 and by Gandouin (2003). During the marine regression, the basin was occupied by a fluvial and marsh system (Van der Woude and Roeleveld, 1985).

Today, the tempered oceanic climate of the St-Omer region is marked by an annual rainfall of c. $800 \mathrm{~mm}$; the mean temperatures of the warmest and coldest months are about $18^{\circ} \mathrm{C}$ and $3^{\circ} \mathrm{C}$, respectively, and the mean annual temperature is close to $10.5^{\circ} \mathrm{C}$ (Gehu, 1970). The modern landscape is a mosaic of cultivated and built up areas, with scattered remnants of seminatural marsh vegetation consisting of willow and alder woodland, peat-bogs and wet grasslands.

\section{Material and methods}

\section{Field work}

Core sampling was carried out in the St-Momelin marsh. Two corers were used: (i) a $10 \mathrm{~cm}$ piston corer to extract the 'S2' core, which reached a depth of $1800 \mathrm{~cm}$; and (ii) a $15 \mathrm{~cm}$ screw auger to extract a further core below S2, named 'P14'. The P14 profile allowed us to reach the Tertiary bedrock surface at a depth of $2000 \mathrm{~cm}$, and therefore to complete the $\mathrm{S} 2$ profile. The two profiles are located $3 \mathrm{~m}$ apart. The deposits from $0-1 \mathrm{~m}$ were not sampled because of possible disturbance by agricultural activities. Sediments from 3-6 m, 9.64-10.05 $\mathrm{m}$ and $11.5-12 \mathrm{~m}$ were lost during coring operations. The sandy-silty sediments, from $1-3 \mathrm{~m}, 10.4-13 \mathrm{~m}$ and $15.5-17.5 \mathrm{~m}$ on the $\mathrm{S} 2$ profile, were sterile in terms of fossil preservation.

\section{Chronology and lithostratigraphy}

The radiocarbon ages obtained from bulk peat samples (Table 2) were calibrated with the INTCAL98 calibration curve, using the intercept method (Stuiver et al., 1998). The lithological similarity of the S2 and P14 profiles (Figure 2) and radiocarbon dating allowed us to: (i) correlate the two profiles in order to draw a synthetic log and; (ii) chronologically place the sedimentary history of the site into a regional sedimentological context. The dates $8610 \pm 70$ and $7740 \pm 60 \mathrm{BP}$ are very close stratigraphically (P14 profile), situated at 1625 and $1600 \mathrm{~cm}$, respectively, which suggests that a hiatus occurred that may be correlated with a probable emersion of the site. Similarily, in the S2 profile, the dates taken from the peat between 970 and $1050 \mathrm{~cm}$ are extremely close in the chronology, this is probably because this segment of the core corresponds to re-sedimented peat (Gandouin et al., 2005). 


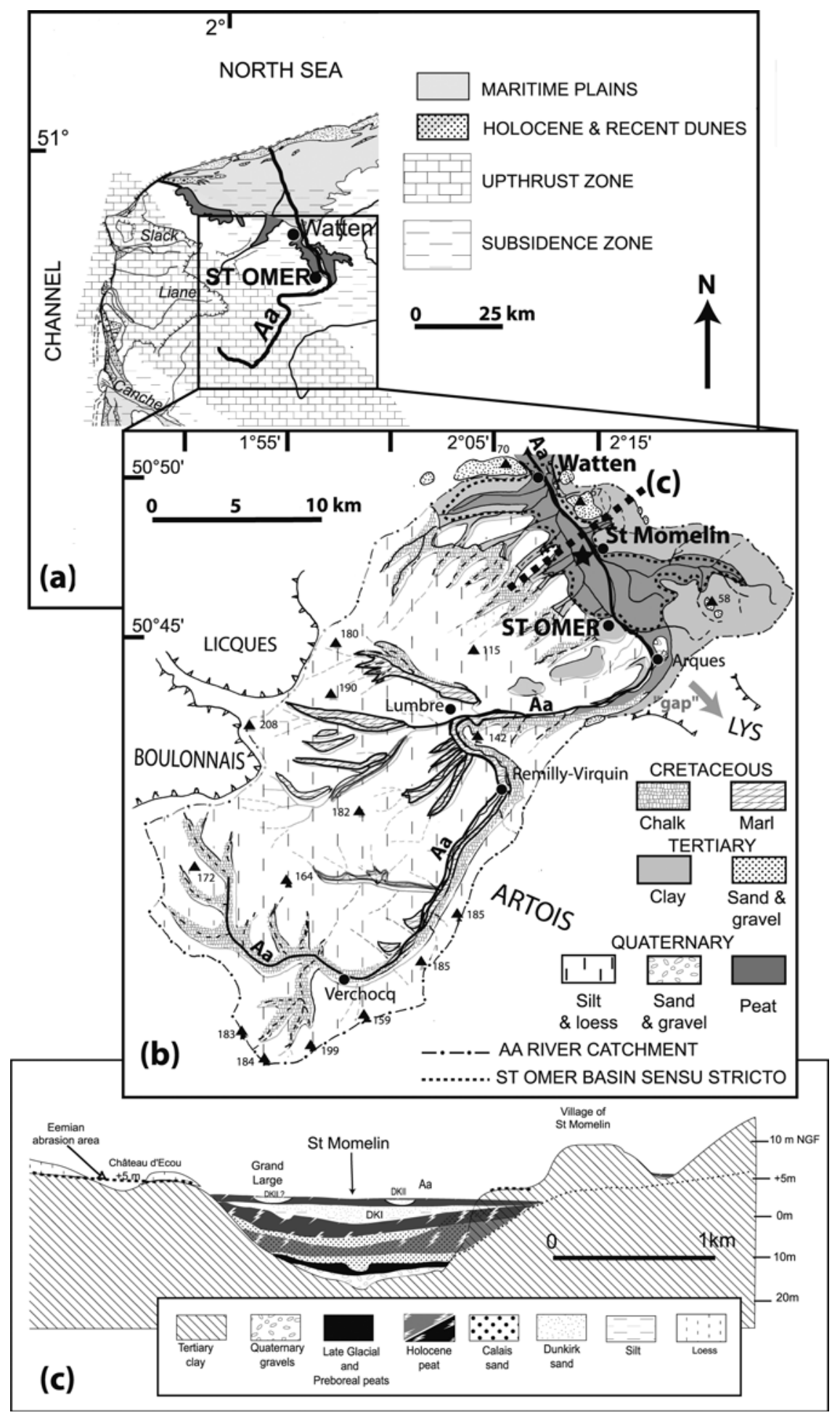

Figure 1 (a) Location of the St-Omer basin (northern France). (b) Drainage basin of the river Aa and coring site (black star). The St-Omer basin sensu stricto is delimited by a dotted line. (c) Lithology of the St-Omer basin cross-section at St-Momelin (Gandouin, 2003)

\section{Subfossil chironomid analysis}

Ninety-two samples of sediment weighing 150 to $500 \mathrm{~g}$ were collected, on average at $11 \mathrm{~cm}$ intervals, at depths ranging from 1900 to $600 \mathrm{~cm}$. The laboratory methods for the extraction and identification of subfossil remains are described in Gandouin et al. (2005) and consisted of a coupled method, with successive sediment $\mathrm{KOH}$-defloculation, water-washing over a $100 \mu \mathrm{m}$ sieve (Hofmann, 1986) and paraffin flotation (Coope, 1986; Ruiz et al., 2006). A minimum of 50 head capsules per sample must be picked out in order to provide realistic estimates of environmental conditions (Quinlan and Smol, 2001b). Taphonomic implica- tions of floodplain and lake assemblages have been discussed by Ruiz et al. (2006). However, in higher energy environments mechanical fragmentation of the head capsules may make identification problematic. In floodplain sediments (silt, gyttja, charophytic mud and peat) from lower energy areas, head capsules were abundant and perfectly preserved, allowing reliable identification to be made to the genus level, and in some cases to the species or species-group level. The identification criteria were based on Bryce (1960), Bryce and Hobart (1972), Cranston (1982), Ferrarese and Rossaro (1981), Rieradevall and Brooks (2001), Rossaro (1982), Schmid (1993) and Wiederholm (1983). 
Table 1 Calais and Dunkerque transgressions and their ages (conventional ${ }^{14} \mathrm{C}$ dates BP) at StMomelin, in Netherlands (Hageman, 1969) and in Lower Saxony (Behre, 2004)

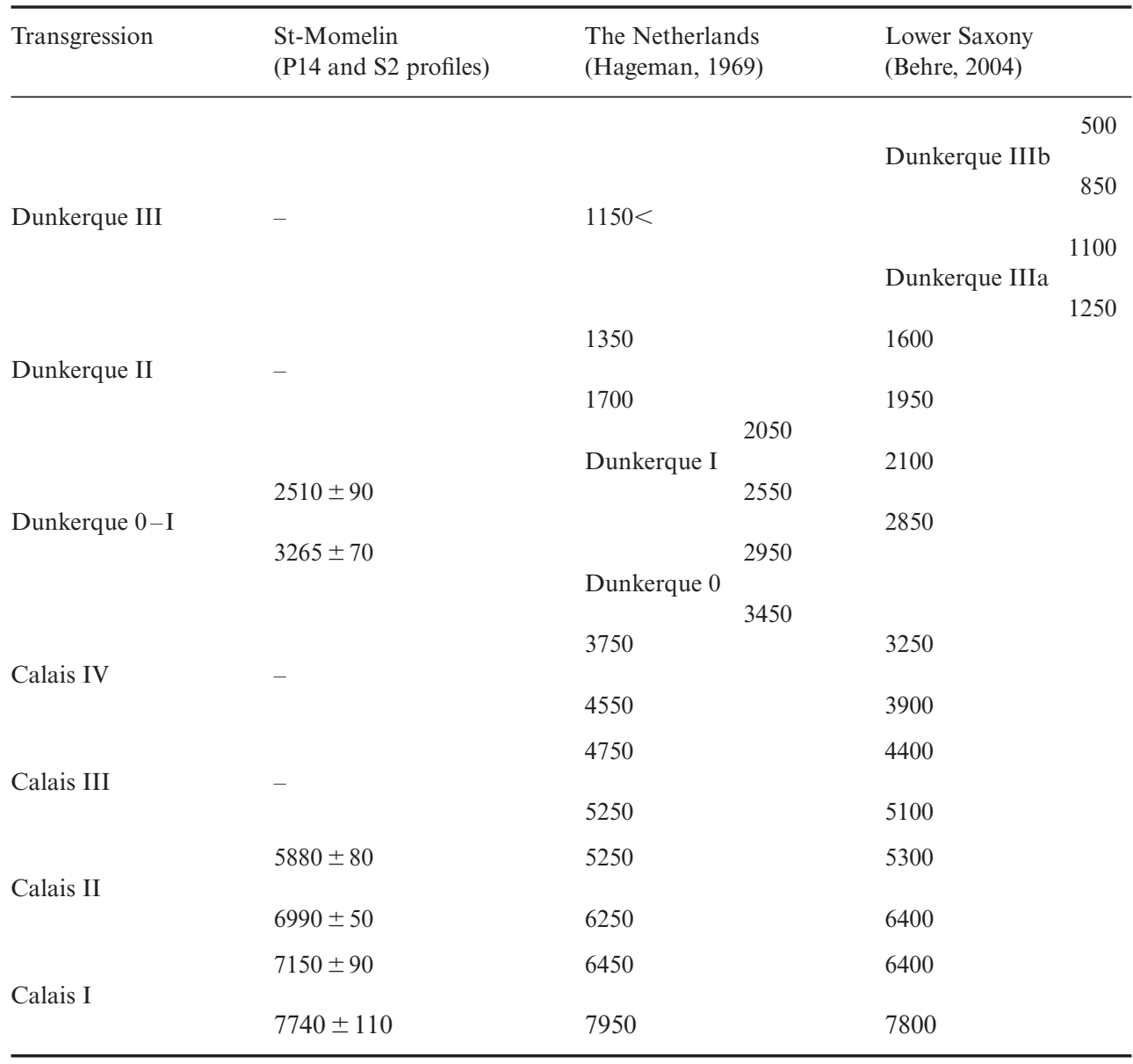

Table $2{ }^{14} \mathrm{C}$ dates assigned to sediments from St-Momelin

\begin{tabular}{|c|c|c|c|c|c|}
\hline $\begin{array}{l}\text { Profile: depth } \\
\text { (cm) }\end{array}$ & $\begin{array}{l}\text { Laboratory } \\
\text { identification } \\
\text { code }\end{array}$ & $\begin{array}{l}{ }^{13} \mathrm{C} /{ }^{12} \mathrm{C} \\
\text { ratio }\end{array}$ & $\begin{array}{l}\text { Conventional } \\
{ }^{14} \mathrm{C} \text { age } \mathrm{BP}\end{array}$ & $(2 \sigma)$ Calibrated BP & $(2 \sigma)$ Calibrated $\mathrm{BC}$ \\
\hline $\mathrm{S} 2: 50-54$ & $\mathrm{Hv}-24816$ & $-29.3 \mathrm{o} / \mathrm{oo}$ & $1975 \pm 45 \mathrm{BP}$ & $1960-1870$ & $10 \mathrm{BC}-\mathrm{AD} 80$ \\
\hline S2: 76-79 & $\mathrm{Hv}-24815$ & $-31.9 \mathrm{o} / \mathrm{oo}$ & $2510 \pm 90 \mathrm{BP}$ & $2745-2360$ & 795 вС -410 \\
\hline S2: 600 & $\mathrm{Hv}-24814$ & $-29.7 \mathrm{o} / \mathrm{oo}$ & $3265 \pm 70$ & $3565-3385$ & $1615-1435$ \\
\hline S2: 800 & Beta-161064 & $-29.0 \mathrm{o} / \mathrm{oo}$ & $4850 \pm 70$ & $5720-5460$ & $3770-3510$ \\
\hline S2: 900 & Beta-161063 & $-30.0 \mathrm{o} / \mathrm{oo}$ & $5830 \pm 100$ & $6870-6410$ & $4920-4460$ \\
\hline S2: 1025 & Hv-24813 & $-30.0 \mathrm{o} / \mathrm{oo}$ & $5880 \pm 80$ & $6840-6635$ & $4890-4685$ \\
\hline S2: 1400 & Beta-161062 & $-28.5 \mathrm{o} / \mathrm{oo}$ & $6990 \pm 50$ & $7940-7700$ & $5990-5740$ \\
\hline S2: 1530 & $\mathrm{Hv}-24812$ & $-30.5 \mathrm{o} / \mathrm{oo}$ & $7150 \pm 90$ & $7990-7830$ & $6040-5880$ \\
\hline S2: 1723 & Beta-161061 & $-28.3 \mathrm{o} / \mathrm{oo}$ & $7740 \pm 110$ & $\begin{array}{l}8960-8940 / 8850-8840 / \\
8780-8350\end{array}$ & $\begin{array}{l}7010-6980 / 6900-6890 / \\
6830-6400\end{array}$ \\
\hline P14: 650 & $\mathrm{Hv}-24808$ & $-28.9 \mathrm{o} / \mathrm{oo}$ & $4180 \pm 45$ & $4825-4575$ & $2875-2625$ \\
\hline P14: 700 & $\mathrm{Hv}-24807$ & $-29.0 \mathrm{o} / \mathrm{oo}$ & $5040 \pm 55$ & $5890-5720$ & $3940-3770$ \\
\hline P14: 1000 & $\mathrm{Hv}-24806$ & $-29.7 \mathrm{o} / \mathrm{oo}$ & $5810 \pm 50$ & $6710-6540$ & $4760-4590$ \\
\hline P14: 1600 & Beta-161065 & $-28.1 \mathrm{o} / \mathrm{oo}$ & $7740 \pm 60$ & $8620-8400$ & $6670-6450$ \\
\hline P14: 1625-1630 & Beta-161066 & $-28.2 \mathrm{o} / \mathrm{oo}$ & $8610 \pm 70$ & $9720-9500$ & $7770-7550$ \\
\hline P14: 1700 & Beta-161067 & $-29.1 \mathrm{o} / \mathrm{oo}$ & $9450 \pm 70$ & $11070-10940 / 10860-10520$ & $9120-8990 / 8910-8570$ \\
\hline
\end{tabular}

The calibrated age ranges were based on the INTCAL98 calibration procedure, using the intercept method (Stuiver et al., 1998). All measurements were performed on bulk sediment with a conventional radiocarbon dating procedure.

Chironomid collection slides from the Natural History Museum of London (S.J. Brooks, unpublished works) were also consulted. The relative abundance of each chironomid taxon for each sample is presented as a percentage diagram (Figure 3). A constrained sum-of-squares cluster analysis (CONISS) for percentage data was performed to highlight major changes in chironomid assemblage composition throughout the stratigraphy (Grimm, 1987). Correspondence analysis (CA) was performed on the $n$ by $p$ matrix of percentages to produce an ordination of the $p$ taxa and of the $n$ samples. Rare taxa were removed from the analysis. CA sample scores reflect the relative position of each sample (characterized by a specific faunal 


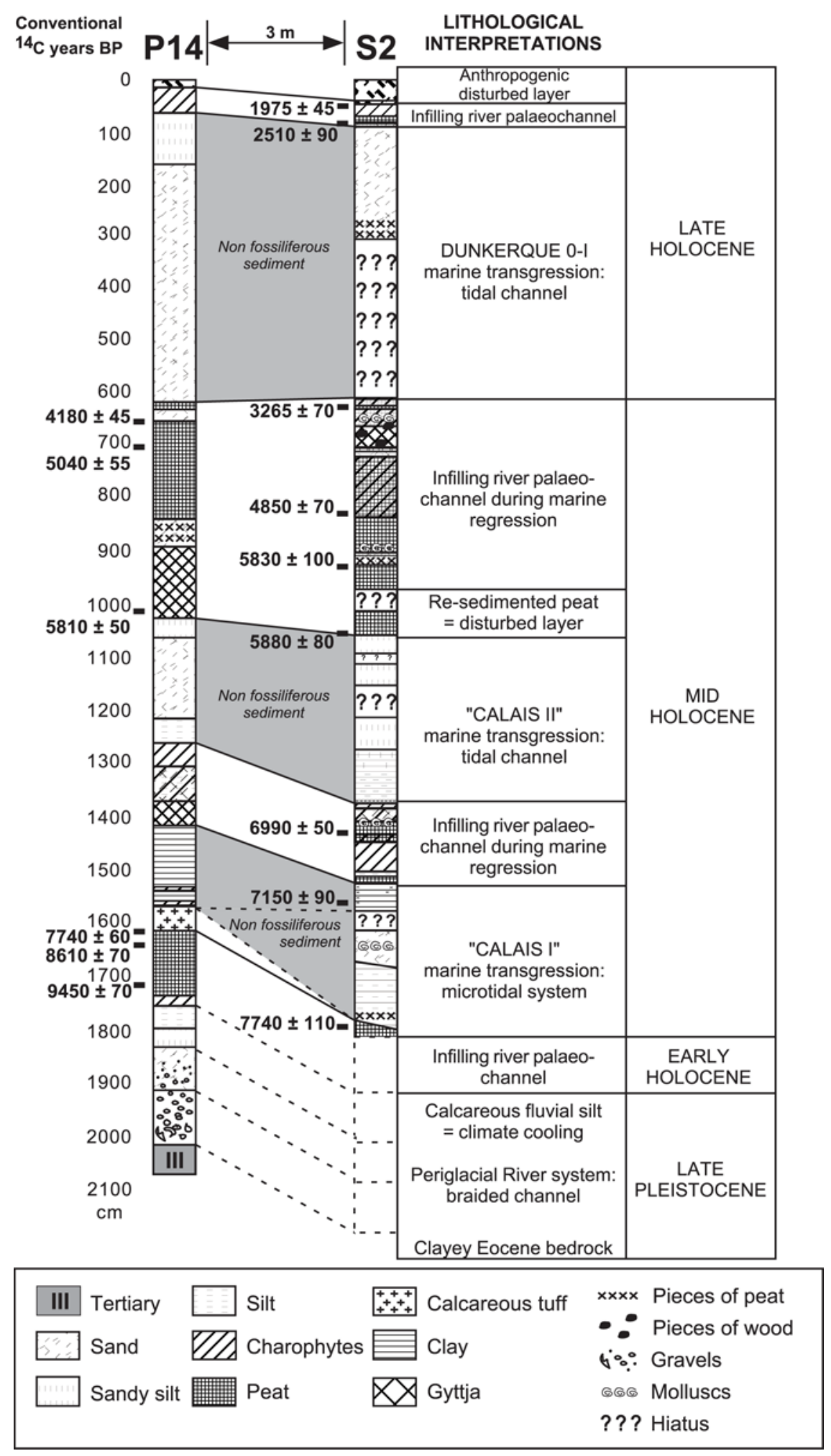

Figure 2 Lithological correlation between P14 and S2 sedimentary profiles

assemblage) among all samples in response to one or more environmental gradients. These scores give an estimate of the overall compositional change between two adjacent samples. The CA and its corresponding graphical plots (Figure 4) were performed in ADE-4 (Thioulouse et al., 1997).

\section{Chironomid ecological preferences and temperature estimates}

The habitat preferences of flood plain chironomids are discussed in Gandouin et al. (2005, 2006). Following Gandouin et al. (2006), the chironomid assemblages are grouped into four ecological categories (Figure 5): (i) lentic: chironomid genera associated with lentic habitats such as oxbow lakes, dead-arms, side channels temporarily connected with main channel; (ii) lotic: genera associated with lotic habitats such as the main channel and side channels, connected to the main river; (iii) ubiquitous: genera that can colonize all kinds of habitats available in the river floodplain; and (iv) unclassified: taxa that cannot be precisely identified and/or taxa with a distribution that is either unknown or unrelated to the flow rate of the current. 
A second independent grouping is based on trophic and thermal preferences with: (i) eutrophic and warm-water adapted taxa; (ii) oligotrophic and cold-water adapted taxa; and (iii) indifferent taxa.

The method used here to produce temperature estimates is based on the only data set available in Europe, obtained by Rossaro (1991) and Rossaro et al. (2006), from an altitudinal range of 991 sites in running waters (northern Italy). Temperature estimates are represented graphically according to the Tukey boxplot method (Tukey, 1977; Wonnacott and Wonnacott, 1990).

\section{Results: palaeoenvironmental reconstruction}

One hundred and eleven taxa (see Gandouin, 2003) were identified from 92 levels. A mean number of 78 head capsules per sample were counted ( $n_{\min }=53$ capsules, $n_{\max }=154$ ), totalling 7157 head capsules. Three major zones (Zone 1, 2 and 3) and 16 subzones (Subzone SMch-1 to SMch-16) were identified by the cluster analysis (Figure 3).

The first two axes of the CA (Figure 4A, B) account for nearly $25 \%$ of the total inertia contained in the 92 (samples) by 79 (taxa) matrix. The first axis shows a gradient between Zone 1 and 2, with Zone 3 located in an intermediary position. The first axis separates the warm-water adapted, eutrophic and limnophilous taxa, such as Chironomus spp. and Dicrotendipes spp., from the cold-water adapted, oligotrophic and rheophilous taxa, such as Paracladius sp., Micropsectra spp., Diplocadius cultriger, Tanystarsus lugens grp., EukiefferiellalTvetenia and Cricotopus/Orthocladius/Paratrichocladius. Hence, the first axis could be interpreted as a thermal gradient. Based on this interpretation, the thermal optimum occurs in the final part of Zone 2, and the cold maximum in Zone 1 (Figure 4C).

\section{Zone-1 (1894-1747 cm) $\leq$ 9450 $\pm 70 \mathrm{BP}$}

Zone-1 is characterized by Cricotopus/Orthocladius/ Paratrichocladius, Paracladius sp., Micropsectra spp., Eukiefferiella/Tvetenia and Tanytarsini unidentified. These taxa are mostly adapted to cold water, and following Gandouin et al. (2006), they are considered to be a lotic community that is typical of a river floodplain.

In SMch-1 $(1894-1846 \mathrm{~cm})$, despite of the dominance of lotic taxa, the presence of lentic species, such as Polypedilum spp. and Microtendipes spp. (which are usually located in lacustrine littoral areas) is consistent with shallow and slow water flow. Many stream species of the Micropsectra spp. and Eukiefferiella/Tvetenia genera are also known to be oligotrophic (Brodersen et al., 2004) and cold-water adapted (Rossaro, 1991; Rossaro et al., 2006), and indicative of good water quality (Mandaville, 2002). These characteristics are all consistent with cold climate conditions.

SMch-2 $(1834-1786 \mathrm{~cm})$ is characterized by a change in the assemblage, with a decrease of lotic taxa and a dominance of the cold-water adapted Paracladius (Brooks et al., 1997; Walker et al., 1997). Many cold-water adapted and oligotrophic taxa, such as Diplocladius cultriger (Oliver and Dillon, 1997), Paracladopelma sp. (Lotter et al., 1997) and Heleniella serratosioi (Bulankova et al., 2001) sporadically appear in this subzone. This faunal change could be linked to a cold maximum.

In SMch-3 $(1761-1747 \mathrm{~cm})$ the chironomid evidence suggests that climate conditions were still harsh, but relatively warmer than in SMch-2, with slightly higher percentages of eutrophic and warm-water adapted taxa.
The zone-1 dynamics of the chironomid assemblage allow us to: (i) discriminate two phases in the water flow rate, SMch-1 versus SMch-2 and 3, the latter two being more stagnant than the previous one; and (ii) suggest that a cold period is recorded in the St-Omer deposits, with a cold maximum during SMch-2.

\section{Zone-2 $(1737-1305 \mathrm{~cm})$ from $c .9500$ to $7000 \mathrm{BP}$}

Zone-2 is contemporaneous with the early Holocene and the Calais transgression. In the lower and upper part of the Calais deposits $(1800-1555 \mathrm{~cm}$ and $1300-1045 \mathrm{~cm})$ of the $\mathrm{S} 2$ profile, no chironomids were found in the sandy deposits. This could be explained by either rapid sedimentation or poor conservation of chitinous remains resulting from oxidation and abrasion processes. Zone-2 is mainly characterized by Chironomus spp., Dicrotendipes spp., Polypedilum spp., Stempellina sp. and Microtendipes spp. These taxa mostly fall within the cateogory of 'lentic-ubiquitous' as they are eutrophic taxa that are adapted to warm water; as such, they mark the climatic improvement of the Holocene. Such assemblages also suggest that the habitat became progressively lentic and eutrophic by the organic infilling of the site. This probably would have resulted in a shallow oxbow lake or the dead arm of a stream with stagnant fresh water and a low dissolved oxygen content.

In SMch-4 $(1737-1717 \mathrm{~cm})$ the persistence of cold-water adapted Parametriocnemus/Paraphaenocladius and Limnophyes taxa suggests that in spite of temperate summers, cold water probably persisted in spring, as a result of cold and long winters. These taxa are also semi-terrestrial (Wiederholm, 1983; Delettre, 2005) and their presence may be related to the lowering of water levels induced by the infilling of the site. Moreover, Parametriocnemus/Paraphaenocladius are also taxa that are known to be typical of running-water (Heiri and Lotter, 2003), therefore the site was probably connected with the main channel during part of the year, explaining the cooler water inputs.

In SMch-5 (1710-1632 cm) the increase of Microtendipes spp., which is usually known as a littoral lacustrine taxon (Brooks, 2000), suggests that the infilling of the palaeochannel continued. The upper and lower limits of the subzone are marked by two isolated events. The first event, at the lower limit, corresponds to a peak of Polypedilum spp. This ubiquitous taxon could suggest an intermediate stage between a predominantly 'lotic' system (cf. SMch-4) and a lentic and shallow hydrosystem (SMch-5). The second event is marked by a peak in the oligotrophic and coldwater adapted Micropsectra spp., which is also considered as lotic in a floodplain environment (Gandouin et al., 2006). This may indicate a reconnection of the site with the river channel, probably as a consequence of a flood. No evidence of an abrupt flood event, such as a coarse minerogenic deposit, is given by the lithology, but a groundwater flood is probable. Moreover, groundwater, usually being cooler than surface water, would have enabled cold-water adapted taxa to appear. A climatic cooling could also be used to explain the peak of Micropsectra spp. and the occurrence of several cold stenothermous taxa, such as Heleniella seratosioï and Conchapelopia melanops.

SMch-6 $(1625-1611 \mathrm{~cm})$ is characterized by the ubiquitous Chironomus spp. and Polypedilum spp. The site was probably situated between the lotic and lentic habitats of the river floodplain. Many species of the Chironomus and Polypedilum taxa are associated with mesotrophic to eutrophic environments and large amounts of fine organic matter (Millet, 2004). In lakes from low-arctic West Greenland, Brodersen et al. (2004) have shown that Chironomus larvae have a high oxy-regulatory capacity and are thus able to spend a proportion of their lifecycle under hypoxic or apoxic conditions. This could indicate a 


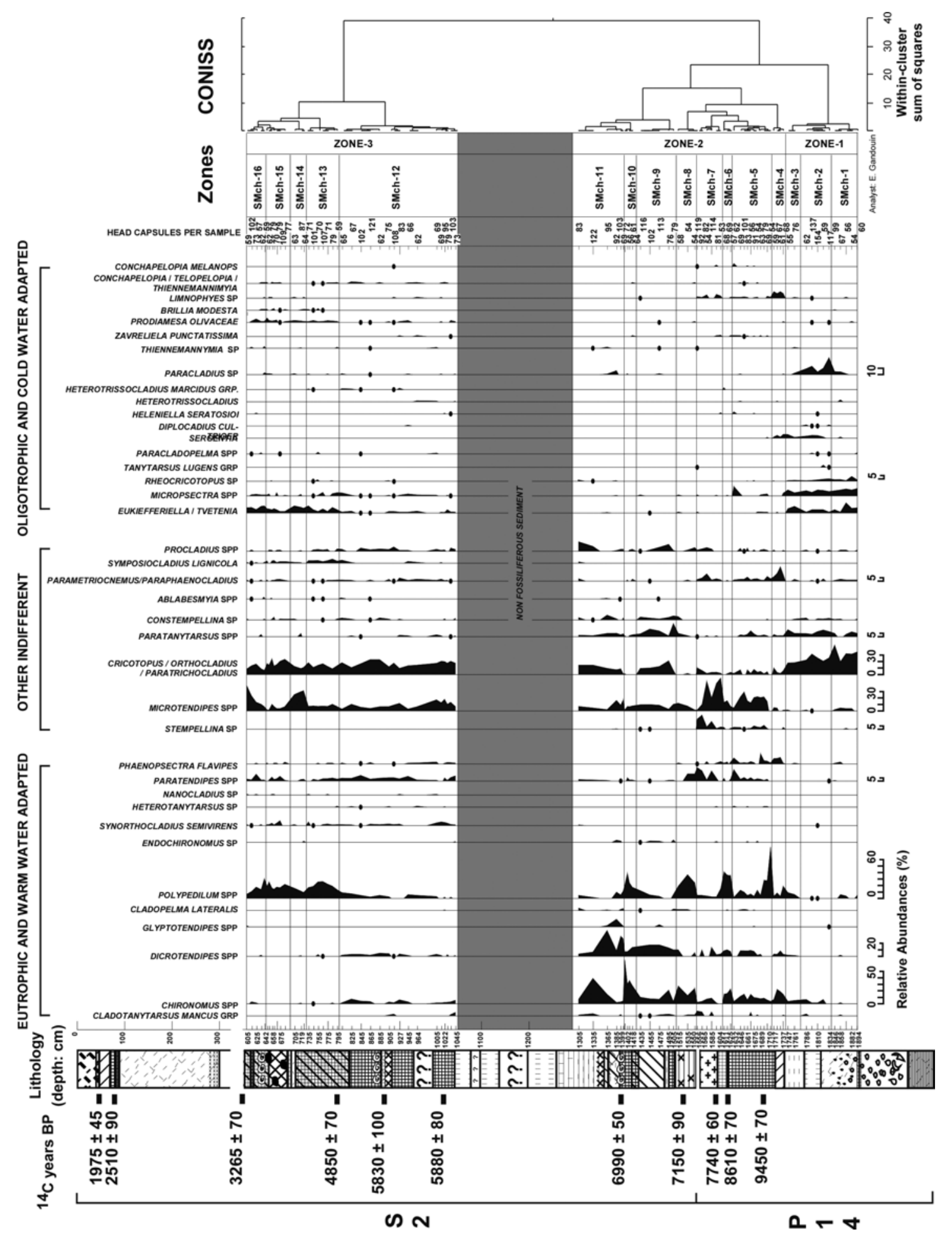

官官

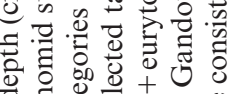

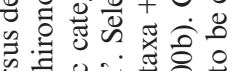

矛势记

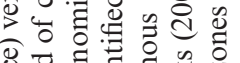

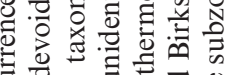

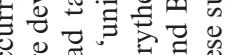

ช.

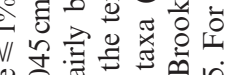

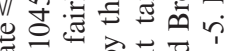

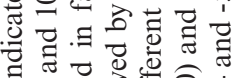

ज चี

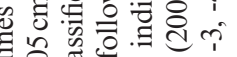

चु

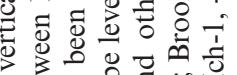

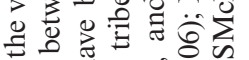

of

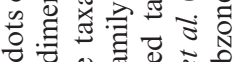

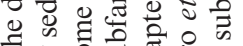

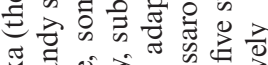

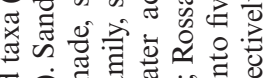

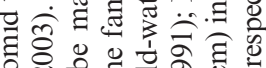

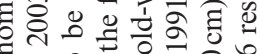

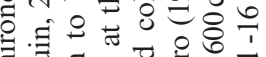

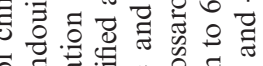

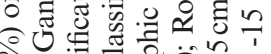

过它苛

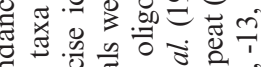

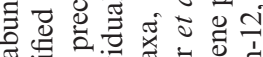

政

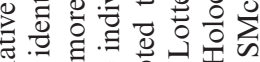

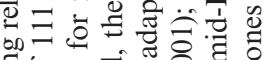

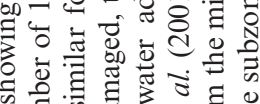

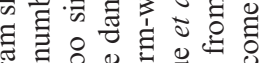

要

은

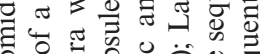

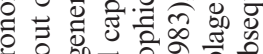

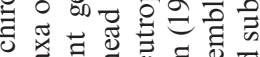

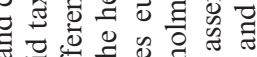

ㅎㅇ च

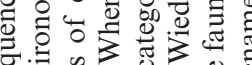

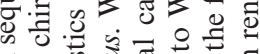

毛罗要

क人

फे

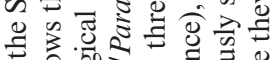

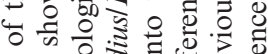

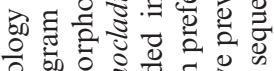

을

芫

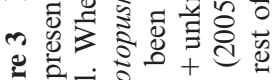

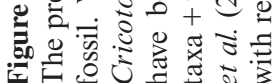



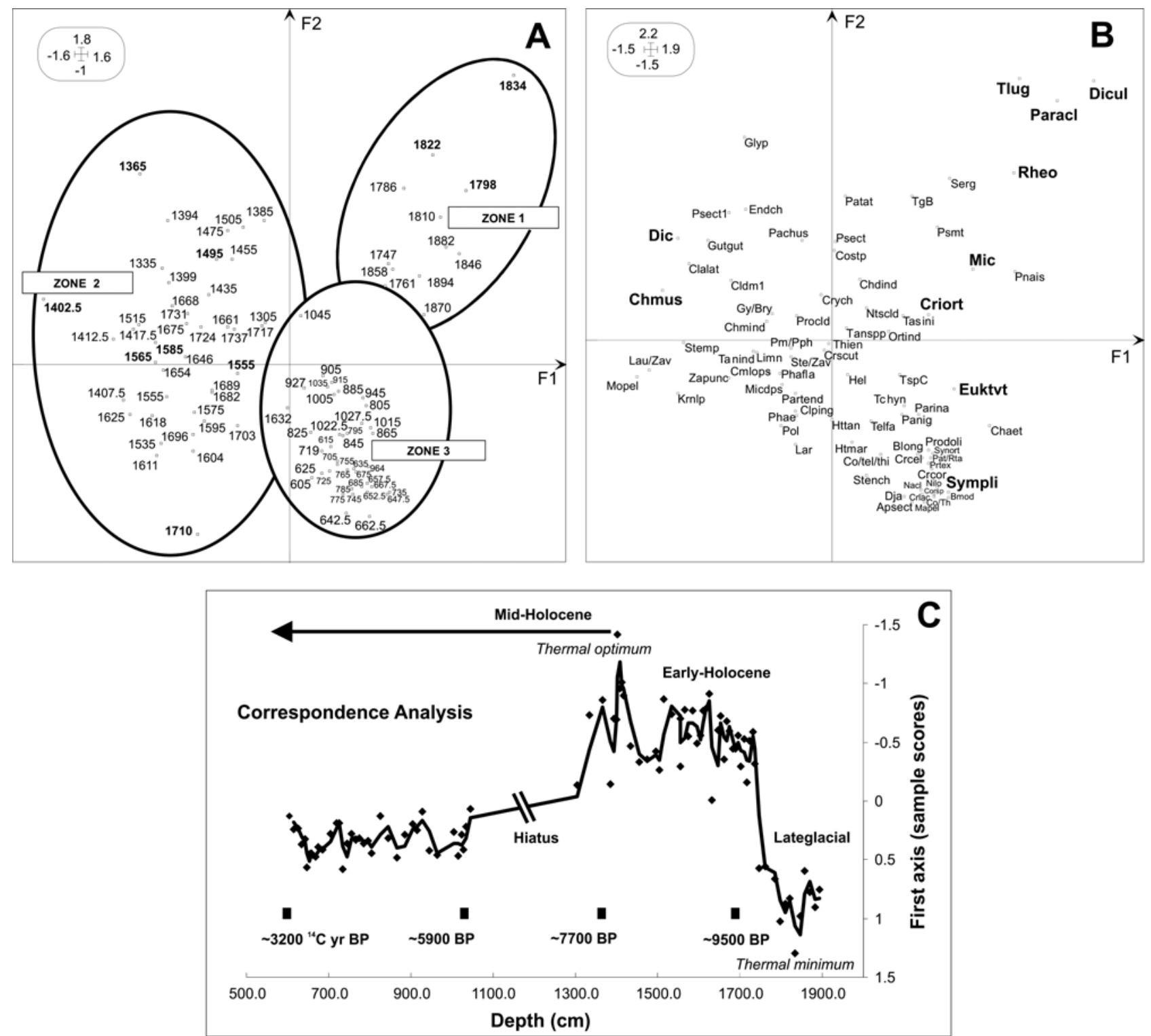

Figure 4 Factorial plane F1-F2 (accounting for 25\% of the total inertia) from a Correspondence Analysis. (A) Plot of axes F1 and F2 for the 92 analysed samples. (B) Plot of axes F1-F2 of the chironomid taxa ( $n=76$; rare taxa have been excluded from the analysis). (C) Correspondence Analysis sample scores for F1 axis. In bold: taxa that contribute to the first axis. Abbreviations: Apsect, Apsectrotanypus trifascipennis; Blong, Brillia longifurca; Bmod, Brillia modesta; Chaet, Chaetocladius sp; Chdind, unidentified Chironomidae; Chmind, unidentified Chironomini; Chmus, Chironomus spp.; Clalat, Cladopelma lateralis; Cldm1, Cladotanytarsus mancus group; Clping, Clinotanypus pinguis; Cmlops, Conchapelopia melanops; Co/Tel/Thi, Conchapelopia/Telopelopia/Thiennemannimyia; Co/Th, Corynoneura/Thiennemaniella; Corsp, Corynoneura sp.; Costp, Constempellina sp.; Crcel, Corynoneura celeripes (cf. antennalis); Crcor, Corynoneura coronata; Criort, Cricotopus/Orthocladius/Paratrichocladius; Crlac, Corynoneura lacustris; Crscut, Corynoneura scutellata type; Crych, Cryptochironomus sp.; Dic, Dicrotendipes spp.; Dicul, Diplocadius cultriger; Endch, Endochironomus sp.; Euktvt, Eukiefferiella/Tvetenia; Glyp, Glyptotendipes spp.; Gutgut, Guttipelopia guttipennis; Gy/Bry, Gymnometriocnemus/Bryophaenocladius; Hel, Heleniella seratosioi; Htmar, Heterotrissocladius marcidus grp.; Htscld, Heterotrissocladius sp.; Httan, Heterotanytarsus sp.; Krnlp, Krenopelopia sp.; Lar, Larsia sp.; Lau/Zav, Lauterborniella/Zavrelliella; Limn, Limnophyes sp.; Mapel, Macropelopia; Mic, Micropsectra spp.; Micdps, Microtendipes spp.; Mopel, Monopelopia tenuicalcar; Nacl, Nanocladius sp.; Nilo, Nilotanypus dubius; Ortind, unidentified Orthocladiinae; Pachus, Parachironomus sp.; Paracl, Paracladius sp.; Panig, Paralauterborniella nigrohalteralis; Parina, Paramerina sp.; Partend, Paratendipes spp.; Pat/Rta, Para/Rheo-tanytarsus; Patat, Paratanytarsus spp.; Phae, Phaenopsectra sp.; Phafla, Phaenopsectra flavipes; Pm/Pph, Parametriocnemus/Paraphaenocladius; Pnais, Paracladopelma nais; Pol, Polypedilum spp.; Procld, Procladius spp.; Prodoli, Prodiamesa olivaceae; Prtex, Paratrissocladius excerptus; Psect, Psectrocladius spp.; Psmt, Pseudosmittia sp.; Rheo, Rheocricotopus sp.; Serg, Sergentia sp.; Ste/Zav, StempellinellalZavrelia; Stemp, Stempellina sp.; Stench, Stenochironomus sp.; Sympli Symposiocladius lignicola; Synort, Synorthocladius semivirens; Tanind, unidentified Tanypodinae; Tanspp, Tanytarsus spp.; Tchyn, Tanytarsus Chyniensis; Tasini, unidentified Tanytarsini; Telfa, Telopelopia fascigera; TgB, Tanytarsina gp. B; Thien, Thiennemannymia sp.; Tlug, Tanytarsus lugens grp; TspC, Tanytarsina sp. C; Zapunc, Zavreliela punctatissima 
possible depletion of oxygen in the water column, probably during a phase of water stagnation.

SMch-7 $(1604-1556 \mathrm{~cm})$ is marked by the dominance of Microtendipes spp., which could suggest shallow standing water, as observed in SMch-5. However, SMch-7 differs by having higher percentages of Stempellina sp. and Paratendipes spp. These taxa prefer high $\mathrm{pH}$ values (Mousavi, 2002), which are consistent with the contemporaneous chalky deposits (calcareous tuff layer in Figure 2). These sediments may have been the result of carbonate precipitation due to evaporation processes in a thin water film, or to intense bacterial activities. The abundance of the detritivores Paratendipes and Microtendipes (Stribling et al., 1998) suggests that plenty of organic matter was available, a condition favourable to such bacterial activities. In SMch-7 the cold-water adapted taxa such as Limnophyes sp. and Conchapelopia menalops suggest the possibility of a temporary phase of cold water that was induced by the persistence of cool climate conditions.

SMch-8 $(1555-1515 \mathrm{~cm})$ is characterized by the same assemblages as those of SMch-6 and by the dominance of ubiquitous Chironomus spp. and Polypedilum spp., which are also oxyregulators, and adapted to eutrophic and warm waters. During SMch-8, almost all oligotrophic and cold-water adapted taxa disappear. Throughout this subzone, water was probably eutrophic and relatively warm, with low a oxygen content because of a highly productive ecosystem, where metabolic activities of plants and micro-organisms are stimulated by nutrient profusion and warm summer waters. Such assemblages also could have been induced by brackish conditions (Tourenq, 1975) due to probable marine water influx (tidal or storm activity).

In SMch-9 $(1505-1435 \mathrm{~cm})$ the percentages of eutrophic and warm-water adapted taxa are still very high, whereas the high occurrence of Dicrotendipes spp. indicates considerable abundance of macrophytic vegetation (Hofmann, 1984), as also suggested by charophyte deposits.

SMch-10 (1418-1402 cm) is characterized by chironomid assemblages similar to those from SMch-8, with an abundance of Chironomus spp. and Polypedilum spp.

SMch-11 $(1399-1305 \mathrm{~cm})$ possesses the same chironomid assemblages, and hence similar ecological conditions, to that of SMch-9. At the end of SMch-11, Dicrotendipes spp. is replaced by Chironomus spp. This could have been induced by maximal oxygen depletion, and/or an increasing marine influence associated with brackish conditions. The latter is supported by the lithology, with the blue-grey silty clay being typical of tidal palaeochannels.

\section{Zone-3 from c. 5900 to 3200 BP}

Zone-3 is marked by the abundance of both standing- (or slowly moving) and running-water taxa. These ecologically contrasting groups are not necessarily incompatible. The presence of both groups suggests a river meandering across its floodplain between pools and riffles. The fact that the sediment included members of both communities suggests that they were accidentally brought together, for instance, at the time of a flood.

Faunal successions throughout zone-3 (from SMch-12 to SMch-16) indicate fluctuations in the hydrological regime, oscillating (Figure 5) between periods with a dominant lentic fauna (SMch-12, SMch-14 and SMch-16) and those with a dominant lotic fauna (SMch-13 and SMch-15). These fluctuations probably indicate that there were alternating episodes of rapid flow interspersed with calmer periods. Gandouin et al. (2005) have already discussed the correlation of the St-Omer lotic phases with several European climatic events known to have occurred during this period, such as alternations between dry and wet periods (Magny et al., 2003). Since the sea level was relatively stable and the coastline was fairly distant from the basin in this part of the mid Holocene, Gandouin et al. (2005) assumed that climate may have been responsible for these fluctuations in the hydrological regime of the River Aa. However, with a possible overestimation of the effects of precipitation due to some orographic processes (the Aa river catchment being located between the 'Boulonnais' and the 'Artois' reliefs), rainfall and flooding may have been concentrated in the lowest part of the river (the St-Omer basin).

This paper adds additional paleaoenvironmental information about zone-3. Comparison between the zone-3 faunal assemblage and the two other subjacent zones reveal the following. (i) Eutrophic and warm-water adapted taxa are always dominant in zone-3, but that cold-water taxa reappear, suggesting that water temperatures were probably lower in zone-3 than in zone-2. (ii) The presence of high numbers of xylophagous taxa, such as Symposiocladius lignicola, Brillia modesta and Synorthocladius semivirens (Rossaro, 1982; Wiederholm, 1983; Walker and Mathewes, 1989) suggests that accumulations of plant debris, probably deposited during floods, were available nearby (this hypothesis is confirmed by the occurrence of wood fragments in the sediment). These data suggest a forest expansion within the catchment basin.

\section{Discussion}

\section{Dating of the basal part of the sequence, based on radiocarbon, sediment and chironomid evidence}

According to Antoine et al. (2000), fluvial silts with a high calcareous content are characteristic of Lateglacial cold periods (Oldest and Younger Dryas). Over much of NW Europe, where valleys cut through the chalk, calcareous muds were produced at this time by substrate gelifraction that accumulated in the valley bottoms (Ponel et al., 2005). In Belgium and The Netherlands such fine and calcareous sand layers underlying early Holocene peat (Munaut and Paulissen, 1973; Berendsen and Stouthamer, 2000) have been dated to the Younger Dryas. However, some Lateglacial minerogenic deposits (some of which have a high calcareous content) are associated with entirely temperate insect assemblages (Coope and Brophy, 1972; Coope, 1998). Thus minerogenic sedimentation alone should not necessarily be taken as an indicator of cold conditions, but independent evidence, such as that derived from the chironomid assemblages, is clearly indicative of cold conditions that, in this case, are in agreement with the sedimentary interpretation. Based on this evidence there can be little doubt that samples from faunal unit SMch-1 to SMch-3 date from the Younger Dryas and that the sudden warming at SMch-4 marks the start of the Holocene.

\section{Impact of Holocene sea level fluctuations on chironomid assemblages}

Some Chironomids, such as Chironomus salinarius, are able to live in full marine conditions (Pinder, 1995; Hofmann and Winn, 2000), and the influence of marine incursions near the estuary of a river is likely to have had effects further upstream, for example in the increase of salt-tolerant species of chironomids. In the sequence sampled at St-Omer there is no chironomid evidence for the durable presence of truly marine conditions. However, from a lithological point of view, there are several types of clay-silt and sand that are characteristic of marine environments (see Allen, 2003, for detailed lithological description and interpretation of tidal palaeochannel deposits). SMch-8, SMch-10 and the top of the SMch-11 may be related to only probable marine water influx induced by short tidal episodes or storm activity. These short marine episodes should 

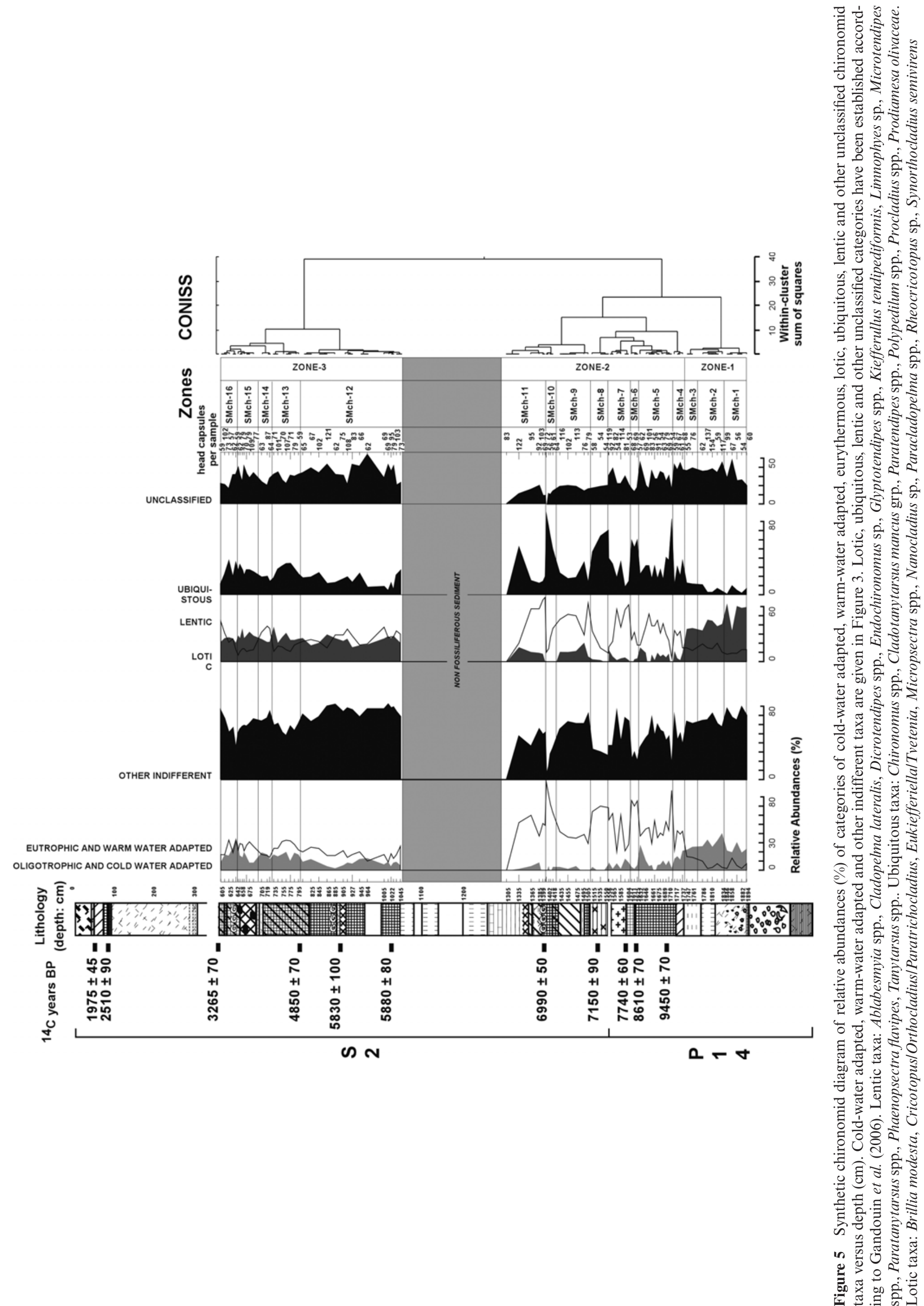
have been favourable to the maintenance of brackish conditions into the basin and the dominance of brackish water tolerant taxa such as Chironomus and Polypedilum (Tourenq, 1975).

At St-Omer, the impact of Holocene sea level fluctuation on chironomid assemblages is therefore especially indirect. Change in the hydrological regime of the basin may have been induced in the following way. (i) A rise in groundwater level during the early Holocene in response to sea level rise; this would have led to the peat infilling of the Lateglacial palaeochannels (Berendsen and Stouthamer, 2000) and water stagnation throughout the basin. (ii) A substantial retreat of the sea from the area at about $6000 \mathrm{BP}$ would have led to an increase in the water flow of the river, and the development of a vast freshwater marshy environment with a great diversification of habitats throughout the Aa river floodplain (Van der Woude and Roeleveld, 1985; Gandouin et al., 2005).

\section{Climatic interpretation and estimation of summer water temperatures}

The present palaeoenvironmental reconstruction shows that chironomid assemblages are primarily dependent on hydrological conditions and river morphology. It is, however, possible to deduce climatic data from chironomid assemblage changes, not only because river morphology is dependent on major climate changes, but also indirectly since such assemblages are in equilibrium with water temperatures, the latter being a key variable for midge adult emergence and thus driving chironomid species distribution (Rossaro, 1991; Rossaro et al., 2006).

Contrary to lake ecosystems, no chironomid transfer function is available for fluvial systems, since factors such as current speed, cool water inputs, sediment erosion, vegetation, transport and deposition are probably more constraining than in lake environments (Gandouin et al., 2006). It is however possible to estimate a range of water summer temperatures from the data set available in Rossaro (1991) and Rossaro et al. (2006), using the Tukey boxplot graphic method (Tukey, 1977; Wonnacott and Wonnacott, 1990). Optimum water temperature was estimated for each chironomid species present in the data set from northern Italy. For each dominant genus occuring in subfossil assemblages at St-Omer, corresponding species values from the Rossaro data base (Table 3 ) are plotted on a diagram (Figure 6) showing graphically the ordinate distribution of temperatures within the different quartiles. Despite the southern location of the chironomid data base, its use in more northerly areas is made possible because of the wide altitudinal range spanned by the 991 sampling sites (from mid-Po fluvial plain to high summits of the Italian Alps). Moreover, the northern Italian chironomid fauna is very similar to the French fauna, according to Serra-Tosio and Laville (1991).

In Zone-1, the modern thermal requirements established in running water for species belonging to the Cricotopus/ Orthocladius/Paratrichocladius group, Micropsectra spp. and Eukiefferiella/Tvetenia group enable us to estimate the thermal conditions that prevailed at St-Momelin: mean water temperatures ranged from $5^{\circ} \mathrm{C}$ to $21^{\circ} \mathrm{C}$, with a median $(\mathrm{Q} 2)$ of about $11^{\circ} \mathrm{C}$ and an interquartile range between $9^{\circ} \mathrm{C}(\mathrm{Q} 1$ : first quartile) and $16^{\circ} \mathrm{C}(\mathrm{Q} 3$ : third quartile). No modern river data are available for the dominant taxa Paracladius. However, according to a data set compiled by Lotter et al. (1997), Paracladius reaches a maximum abundance in Swiss alpine lakes, up to an altitude of $1500 \mathrm{~m}$, with $T_{\text {Jul }}^{\circ}$ air temperatures ranging from $7.0^{\circ} \mathrm{C}$ to $9.6^{\circ} \mathrm{C}$. This is consistent with reconstructed water temperatures ranging from $9^{\circ} \mathrm{C}$ to $11^{\circ} \mathrm{C}$ (interval between Q1 and Q2), since there is a strong correlation between surface water temperature and air temperature (Olander et al., 1999).
In Zone-2, mean water temperatures deduced from the main taxa during the early Holocene ranged from $4^{\circ} \mathrm{C}$ to $22^{\circ} \mathrm{C}$ with a median of about $18^{\circ} \mathrm{C}$ and an interquartile range between $13^{\circ}$ and $21^{\circ} \mathrm{C}$, and $50 \%$ of species had a mean water temperature ranging between $18^{\circ} \mathrm{C}$ and $22^{\circ} \mathrm{C}$. Figure $4 \mathrm{C}$ shows a possible temperature optimum at the onset of the mid Holocene during the Calais transgression.

In Zone-3, summer water temperatures may have been cooler than in Zone-2, since they ranged from about $4^{\circ} \mathrm{C}$ to $22^{\circ} \mathrm{C}$ with a median value of about $12^{\circ} \mathrm{C}$, and an interquartile range between $9^{\circ}$ and $17^{\circ} \mathrm{C}$.

\section{Comparison with other European palaeoenvironmental and palaeoclimatical data}

\section{The Younger Dryas}

During the Younger Dryas, fossil beetle data suggest summer air temperatures $\left(T_{\mathrm{MAX}}\right)$ between $5^{\circ} \mathrm{C}$ and $11^{\circ} \mathrm{C}$ in Britain (Coope, 1998) and between $10^{\circ}$ and $11^{\circ} \mathrm{C}$ in The Netherlands (Bohncke et al., 1987; Van Geel et al., 1989). A pollen record from Luxembourg (Guiot and Couteaux, 1992) provided $T^{\circ}$ Jul of $9^{\circ} \mathrm{C}$, whilst pollen and plant macrofossils from central and NW Europe data sets (Isarin and Bohncke, 1999; Bogaart, 2003) suggest that the climate was characterized by cool summers with temperatures between $12^{\circ}$ and $14^{\circ} \mathrm{C}$. Rensen and Isarin (2001) characterized the major climate transitions in Europe during the last glacial-interglacial transition by comparing maps of January and July temperatures obtained by simulations with an atmospheric general circulation model (ECHAM model) and reconstructions based on geological and palaeoecological data (including beetle and pollen evidence). According to Renssen and Isarin (2001), the St-Omer basin is located between the $10^{\circ}$ and $15^{\circ} \mathrm{C}$ isotherms, this is despite an overestimation of summer temperatures by the ECHAM model and the error margin $\left(1-2^{\circ} \mathrm{C}\right)$ of the pollen-based temperature reconstructions (Isarin and Bohncke, 1999). These data are thus consistent with mean water temperatures ranging from $9^{\circ} \mathrm{C}$ to $11^{\circ} \mathrm{C}$, estimated from the chironomids of St-Momelin, since there is a strong correlation between surface water temperature and $T^{\circ}$ Jul $($ Olander et al., 1999).

Chironomid results from St-Momelin are also in agreement with chironomid-based temperature reconstructions from Britain with summer air temperatures during the Younger Dryas (Loch Lomond stadial) between $9^{\circ} \mathrm{C}$ and $10^{\circ} \mathrm{C}$ at Hawes Water (Bedford et al., 2004) and between $7.5^{\circ} \mathrm{C}$ and $9^{\circ} \mathrm{C}$ at Whitrig Bog (Brooks and Birks, 2000a; Brooks, 2006). Elsewhere in Europe, other chironomid-inferred temperatures for the Younger Dryas provide summer air temperatures of between $9.5^{\circ} \mathrm{C}$ and $10^{\circ} \mathrm{C}$ at Krakenes, Norway (Brooks and Birks, 2000b; Brooks, 2006) and of between $10.4^{\circ} \mathrm{C}$ and $10.9^{\circ} \mathrm{C}$ at the end of the Younger Dryas in the Swiss Alps (Heiri and Lotter, 2003; Heiri et al., 2003).

The Younger Dryas in central and NW Europe is known to be subdivided into an earlier colder and wetter phase followed by a relatively warmer and drier phase (Walker et al., 1994; Isarin et al., 1998; Magny, 2001; Bogaart, 2003). Previous studies of floodplain chironomid subfossils (Gandouin et al., 2005) provided evidence for a close correlation between river hydrological regimes and precipitation; chironomid assemblages characteristic of lotic phases apparently correspond to precipitation increases, whilst lentic phases correspond to precipitation decreases. Our results show a good correlation with this climatic subdivision since the first phase (SMch-1) of the Younger Dryas has a maximum of lotic taxa, whereas the second phase (SMch-2 and 3) is marked by a rise in the lentic taxa. 
Table 3 Correspondence between main chironomid taxa in each zone from St-Momelin and taxa from Rossaro's temperature data base (Rossaro, 1991; Rossaro et al., 2006)

\begin{tabular}{|c|c|c|}
\hline $\begin{array}{l}\text { Main taxa present } \\
\text { at St-Momelin }\end{array}$ & $\begin{array}{l}\text { Taxa present in } \\
\text { Rossaro data base }\end{array}$ & $\begin{array}{l}\text { Mean water } \\
\text { temperature }\left({ }^{\circ} \mathrm{C}\right.\end{array}$ \\
\hline \multicolumn{3}{|l|}{ Zone-1 } \\
\hline \multirow[t]{3}{*}{ Paratrichocladius } & Paratrichocladius nivalis & 6.4 \\
\hline & Paratrichocladius skirwithensis & 6.6 \\
\hline & Paratrichocladius rufiventris & 10.5 \\
\hline \multirow[t]{6}{*}{ Orthocladius } & Orthocladius frigidus & 8.5 \\
\hline & Orthocladius sp. A & 11.1 \\
\hline & Orthocladius rubicundus & 11.8 \\
\hline & Orthocladius excavatus & 12.0 \\
\hline & Orthocladius spp. & 12.3 \\
\hline & Orthocladius pe 1 & 13.0 \\
\hline \multirow[t]{11}{*}{ Cricotopus } & Cricotopus sp. & 10.3 \\
\hline & Cricotopus fuscus & 11.6 \\
\hline & Cricotopus triannulatus & 13.4 \\
\hline & Cricotopus trifascia & 14.8 \\
\hline & Cricotopus vierriensis & 16.6 \\
\hline & Cricotopus annulator & 17.0 \\
\hline & Cricotopus spp. & 17.5 \\
\hline & Cricotopus tremulus & 18.0 \\
\hline & Cricotopus bicinctus & 18.9 \\
\hline & Cricotopus sylvestris & 19.9 \\
\hline & Cricotopus laricomalis & 20.9 \\
\hline \multirow[t]{2}{*}{ Micropsectra spp } & Micropsectra notescens & 9.8 \\
\hline & Micropsectra atrofasciata & 10.4 \\
\hline \multirow[t]{12}{*}{ Eukiefferiella } & Eukiefferiella claripennis & 5.5 \\
\hline & Eukiefferiella brevicalcar & 7.0 \\
\hline & Eukiefferiella devonica & 7.0 \\
\hline & Eukiefferiella fittkaui & 7.4 \\
\hline & Eukiefferiella spp. & 8.0 \\
\hline & Eukiefferiella minor & 8.2 \\
\hline & Eukiefferiella tirolensis & 9.6 \\
\hline & Eukiefferiella fuldensis & 9.7 \\
\hline & * Eukiefferiella hospita & 10.7 \\
\hline & * Eukiefferiella brehmi & 11.8 \\
\hline & Eukiefferiella lobifera & 12.6 \\
\hline & Eukiefferiella clypeata & 16.4 \\
\hline \multirow[t]{3}{*}{ Tvetenia } & Tvetenia bavarica & 7.7 \\
\hline & Tvetenia calvescens & 10.0 \\
\hline & Tvetenia verralli & 17.5 \\
\hline \multicolumn{3}{|l|}{ Zone-2 } \\
\hline \multirow[t]{3}{*}{ Chironomus spp. } & Chironomus spp. & 17.4 \\
\hline & Chironomus riparius & 17.6 \\
\hline & Chironomus plumosus & 20.4 \\
\hline \multirow{8}{*}{ Polypedilum spp. } & Polypedilum quadriguttatum & 11.1 \\
\hline & Polypedilum laetum & 17.4 \\
\hline & Polypedilum cultellatum & 19.2 \\
\hline & Polypedilum convictum & 20.6 \\
\hline & Polypedilum (Tripodura) spp. & 20.9 \\
\hline & * Polypedilum acifer & 21.0 \\
\hline & Polypedilum spp. & 21.4 \\
\hline & Polypedilum nebuculosum & 21.7 \\
\hline Dicrotendipes spp. & Dicrotendipes nervosus & 20.0 \\
\hline \multirow[t]{2}{*}{ Paratendipes spp. } & Paratendipes spp. & 17.3 \\
\hline & Paratendipes nudisquama & 3.8 \\
\hline \multirow[t]{2}{*}{ Microtendipes spp. } & Microtendipes pedellus & 8.9 \\
\hline & Microtendipes spp. & 9.1 \\
\hline \multicolumn{3}{|l|}{ Zone-3 } \\
\hline \multirow[t]{8}{*}{ Polypedilum spp. } & Polypedilum quadriguttatum & 11.1 \\
\hline & Polypedilum laetum & 17.4 \\
\hline & Polypedilum cultellatum & 19.2 \\
\hline & Polypedilum convictum & 20.6 \\
\hline & Polypedilum (Tripodura) spp. & 20.9 \\
\hline & * Polypedilum acifer & 21.0 \\
\hline & Polypedilum spp. & 21.4 \\
\hline & Polypedilum nebuculosum & 21.7 \\
\hline Paratendipes spp. & Paratendipes spp. & 17.3 \\
\hline & Paratendipes nudisquama & 3.8 \\
\hline
\end{tabular}

\begin{tabular}{|c|c|c|}
\hline \multirow[t]{2}{*}{ Microtendipes spp. } & Microtendipes pedellus & 8.9 \\
\hline & Microtendipes spp. & 9.1 \\
\hline \multirow[t]{3}{*}{ Paratrichocladius } & Paratrichocladius nivalis & 6.4 \\
\hline & Paratrichocladius skirwithensis & 6.6 \\
\hline & Paratrichocladius rufiventris & 10.5 \\
\hline \multirow[t]{6}{*}{ Orthocladius } & Orthocladius frigidus & 8.5 \\
\hline & Orthocladius sp. A & 11.1 \\
\hline & Orthocladius rubicundus & 11.8 \\
\hline & Orthocladius excavatus & 12.0 \\
\hline & Orthocladius spp. & 12.3 \\
\hline & Orthocladius pe 1 & 13.0 \\
\hline \multirow[t]{11}{*}{ Cricotopus } & Cricotopus sp. & 10.3 \\
\hline & Cricotopus fuscus & 11.6 \\
\hline & Cricotopus triannulatus & 13.4 \\
\hline & Cricotopus trifascia & 14.8 \\
\hline & Cricotopus vierriensis & 16.6 \\
\hline & Cricotopus annulator & 17.0 \\
\hline & Cricotopus spp. & 17.5 \\
\hline & Cricotopus tremulus & 18.0 \\
\hline & Cricotopus bicinctus & 18.9 \\
\hline & Cricotopus sylvestris & 19.9 \\
\hline & Cricotopus laricomalis & 20.9 \\
\hline \multirow[t]{12}{*}{ Eukiefferiella } & Eukiefferiella claripennis & 5.5 \\
\hline & Eukiefferiella brevicalcar & 7.0 \\
\hline & Eukiefferiella devonica & 7.0 \\
\hline & Eukiefferiella fittkaui & 7.4 \\
\hline & Eukiefferiella spp. & 7.8 \\
\hline & Eukiefferiella minor & 8.2 \\
\hline & Eukiefferiella tirolensis & 9.6 \\
\hline & Eukiefferiella fuldensis & 9.7 \\
\hline & * Eukiefferiella hospita & 10.7 \\
\hline & * Eukiefferiella brehmi & 11.8 \\
\hline & Eukiefferiella lobifera & 12.6 \\
\hline & Eukiefferiella clypeata & 16.4 \\
\hline \multirow[t]{3}{*}{ Tvetenia } & Tvetenia bavarica & 7.7 \\
\hline & Tvetenia calvescens & 10.0 \\
\hline & Tvetenia verralli & 17.5 \\
\hline
\end{tabular}

*Species absent in modern chironomid fauna from France (Serra-Tosio and Laville, 1991).

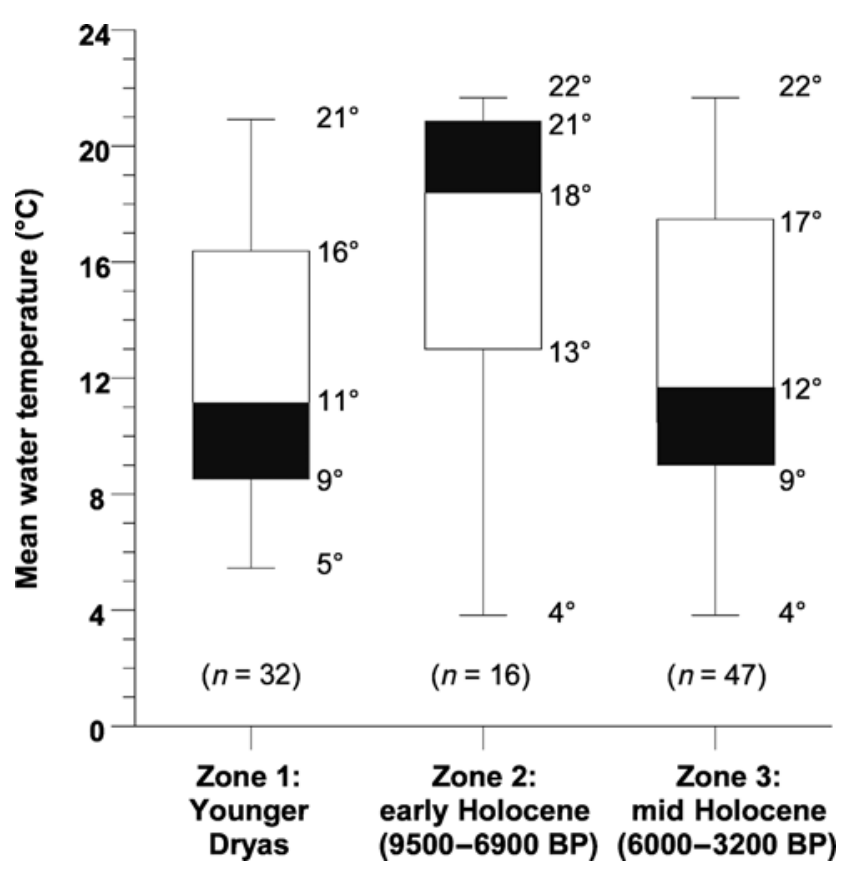

Figure 6 Tukey boxplots from a data set of mean water temperatures (Table 3) based on data from Rossaro (1991) and Rossaro et al. (2006). This preliminary graphic approach allows us to estimate possible mean water temperatures (black area) at St-Momelin during the Lateglacial and Holocene 
At St-Omer, a possible control of the hydrological regime by sea level variations during the Lateglacial can be ruled out for the following reasons. (i) The palaeocoastline was located far away from the St-Omer basin (Scourse and Austin, 1995; Shennan et al., 2000). (ii) Antoine et al. (2000) show that in the Somme and Seine valleys, close to the St-Omer basin, the middle part of river systems are beyond the impact of sea level variations and show detailed responses to climatic variation, especially during the Middle and Upper Pleistocene. (iii) A strong climatic impact on the dynamics of the NW European rivers is observed during the Lateglacial (eg, Starkel, 1991; Huisink, 2000). The climatic factor may be predominant until the early Holocene, since Scourse and Austin (1995) have shown that until c. 9000-8000 years BP, the Southern Bight of the North Sea and the eastern end of the English Channel were both shallow embayments with microtidal processes, and thus are unlikely to have affected the hydrological processes in the St-Omer Basin.

\section{The early Holocene}

The climatic improvement and the change in the fluvial regime of the Holocene are also clearly recorded in the chironomid assemblages. They are seen by the replacement of cold-water adapted and rheophilous taxa by warm-water adapted and limnophilous taxa. Although it is difficult to evaluate the timing of the climate change at St-Momelin because of possible hiatuses, the warming in summer-water temperatures inferred from chironomids (Figure 4C), appears to be related to the rapid warming of the early Holocene reported from fossil beetle data in Great Britain (Atkinson et al., 1987; Coope and Lemdahl, 1995; Coope, 1998), from pollen data in Luxembourg (Guiot and Couteaux, 1992) and, broadly, all over central and NW Europe (Starkel, 1991; Renssen and Isarin, 2001; Davis et al., 2003). This rapid warming is also recorded in fossil chironomid data from more northerly British sites at Hawes Water (Bedford et al., 2004) and Whitrig Bog (Brooks and Birks, 2000a; Brooks, 2006), with summer air temperatures of $13.2^{\circ} \mathrm{C}$ and about $12^{\circ} \mathrm{C}$, respectively. Also, at Kråkenes, Brooks and Birks (2000b) have reconstructed temperatures of $12-13^{\circ} \mathrm{C}$ or more at about $9570 \mathrm{BP}$, however these temperatures are possibly too low because of calibration problems concerning the temperature-inference model.

At St-Momelin, the persistence of cold-water adapted taxa during the early Holocene may be related to a possible temporary switch to a lotic environment marked by colder running water, which is favourable to cold-water adapted species. However, there is no sedimentologic evidence that such a lotic environment existed. The persistence of cold-water adapted taxa may also be explained by two aspects of climate.

(i) Relatively cool temperatures during spring were probably induced by long and cold winters. This explanation is consistent with the January and July isotherms estimated by Zagwijn (1994) at $-2^{\circ} \mathrm{C}$ and $16^{\circ} \mathrm{C}$, which have been based on the presence of indicator species in the pollen records from 9500 to 9000 BP. Zagwijn (1994) located the $-2^{\circ} \mathrm{C}$ January isotherm further south of the St-Omer basin (in the mid-latitudes), whereas the $16^{\circ} \mathrm{C}$ July isotherm was located slightly north of the St-Omer basin. The climate reconstruction for NW Europe proposed by Davis et al. (2003) clearly shows that winter temperatures remained relatively low during the early Holocene whereas summer temperatures were already close to those of the present. This climatic continentality is consistent with the inland position of the St-Omer basin between about 9500 and $8000 \mathrm{BP}$, as shown by a number of studies (eg, Scourse and Austin, 1995; Shennan et al., 2000). (ii) Climate instability and abrupt climatic events, such as the Preboreal Oscillations (PBO), around 11 300-11 150 cal. yr BP (Björk et al., 1997) and the 8200 cal. yr BP event, have been detected at many locations in Europe (Haas et al., 1998; Brooks, 2000; Magny et al., 2001; Björck et al., 2002). Björck et al. (2002) suggest that this period is marked by complex climatic processes, with several short climate oscillations, which may be related to the influx of cold meltwaters from both the North American and European ice sheets and their associated impacts on the North Atlantic thermohaline circulation (Clark et al., 2001; Fisher et al., 2002; Teller et al., 2002). Magny (2004) has noted that additional climate variations between the PBO and the 8200 cal. yr BP event can be also observed in palaeoclimatic records from the North Atlantic area. In northwest England, at Hawes Water, Bedford et al. (2004) have already described a short-lived resurgence of cold water chironomid taxa into the early Holocene, suggesting a period of cooler conditions (maybe PBO). These resurgences, or persistence of cold-water adapted taxa, are also recorded elsewhere in Europe, such as in Norway (Velle et al., 2005), northern Fennoscandia (Korhola et al., 2000, 2002), Britain (Sadler and Jones, 1997), the Swiss Alps (Heiri and Lotter, 2003; Heiri et al., 2003), the Jura (Millet, 2004) and the Southern French Alps (Gandouin and Franquet, 2002). It has therefore been established that chironomids are able to respond to the rapid climatic events that occurred in the early Holocene. A detailed review of these events is given by Brooks (2006).

\section{The mid Holocene}

During the Calais transgression, climate interpretations may be blurred by the impact of sea level rise on the hydrological regime of the St-Omer basin. The abundance of chironomids associated with both macrophytic vegetation and stagnant water is related to the early Holocene transgression. This transgression induced the rise of the groundwater table, the infilling of the palaeochannel and the slowing down of the river flow by the flooding of the basin and the possible water stagnation (Berendsen and Stouthamer, 2000). Regional precipitation increases at the start of the Atlantic (Guiot and Couteaux, 1992) and also may have contributed to the waterlogging of the St-Omer basin.

Summer-water temperatures of between $18^{\circ} \mathrm{C}$ and $22^{\circ} \mathrm{C}$ at St-Momelin are in agreement with Zagwijn (1994) and Guiot and Couteaux (1992) who obtained summer air temperatures close to $18^{\circ} \mathrm{C}$ between 8000 and 7000 BP. However, our values are probably slightly overestimated, as stagnant and shallow waters tend to warm up easily. In addition, high summer insolation during the first part of the Holocene (Mayewski et al., 2004) could have reinforced this warming of the summer waters (and may have also favoured dense vegetation by stimulating photosynthetic processes). Despite this thermal overestimation, the maximum of warm-water adapted taxa (and CA axis 1 scores on Figure 4C) at the onset of the mid Holocene corresponds to the summer thermal optimum reported from fossil chironomid data in Norway (Velle et al., 2005; Brooks, 2006) and all over Europe from palaeobotanical data sets (Zagwijn, 1994; Davis et al., 2003).

From $6800 \mathrm{BP}$ onwards, the chironomids and floodplain vegetation suggest that the St-Omer hydrographic system consisted of a river system that weakly meandered through a vast marshy region (Van der Woude and Roeleveld, 1985). At this time, this type of hydrographic system was widespread throughout northern France (Antoine et al., 2000). The indirect impact of climate, and especially the hydrological regime (precipitation), on chironomids is discussed by Gandouin et al. $(2005,2006)$. According to these authors, lotic phases (SMch-13 and 
SMch-15) are correlated with a wetter mid-European climate (Magny et al., 2003) whereas lentic phases (SMch-12, SMch-14 and Smch-16) are correlated with a drier climate.

Additional information is provided by the present study, which shows that cold-water adapted taxa reappear from about 6800 BP. This return can be explained by several hypotheses.

(i) A probable sea level fall or a slowing in the rate of relative sea level rise could be also envisaged for the St-Omer basin and surrounding area (Berendsen and Stouthamer, 2000; Van VlietLanoë et al., 2004) based on evidence from elsewhere around 5000 conventional radiocarbon yr BP (Bard et al., 1990; Ybert et al., 2003). This event may have induced an increase in the Aa river gradient and in the water flow throughout the basin. By comparison with standing water, running water is less easily warmed during spring and summer, allowing cold-water adapted taxa to emerge.

(ii) The decrease in the rate of the sea level rise induced the development and closing of a coastal barrier (Berendsen and Stouthamer, 2000). In back barrier areas, extensive peat formation is generated by the high groundwater table (Kiden, 1995). The groundwaters may have acted as a thermal buffer on lotic systems during water-table flooding, since they are usually colder than surface water in summer.

(iii) The presence of woodland on the riverbanks is suggested by numerous pieces of wood preserved in the sediments along with wood-mining chironomids. Cool water temperatures could persist because of shading effects.

(iv) Slight cooling in $T_{\text {Jul }}^{\circ}$ from $6000 \mathrm{BP}$ in NW Europe (Huntley and Prentice, 1988; Hammarlund et al., 2002; Davis et al., 2003), combined with a solar radiation decrease (Berger and Loutre, 1991) and neoglaciation in the Northern Hemisphere (Magny et al., 2003) corresponds to the cool water phase indicated by the reappearance of cold-water adapted taxa. Similar trends in declining temperatures obtained from fossil chironomid data are also reported by Velle et al. (2005) and Heiri et al. (2003) in Norway and the Swiss Alps, respectively, and from multiproxy evidence including chironomids in various Swedish lakes (Rosén et al., 2001, 2003; Bigler et al., 2002, 2003).

(v) It is highly probable that a simultaneous occurence of all of these environmental factors occurs at St-Momelin, and leads to a return of cold-water adapted taxa. At present the respective roles of these factors is difficult to evaluate without additional multiproxy evidence.

\section{Conclusion}

Our results suggest that chironomids are an efficient tool for palaeoenvironmental reconstructions in river floodplains since they are strongly influenced by hydrological changes induced by Lateglacial and Holocene climate change. Such change is particularly well marked at the Lateglacial/ Holocene transition through the replacement of cold-water adapted and rheophilous taxa by warm-water adapted and limnophilous taxa in a river switching from a braided to a meandering system.

Despite the influence of the hydrological factor, the present paper has clearly shown that river chironomid assemblages are also controlled by water temperatures. At St-Omer, the impact of climate on chironomid assemblages from the end of the Lateglacial to $c .3200 \mathrm{BP}$ can be summarized as follows.

(i) During the final part of the Lateglacial, rheophilousoligotrophic and cold-water adapted taxa are dominant, and water temperature may have ranged from $9^{\circ} \mathrm{C}$ to $11^{\circ} \mathrm{C}$. (ii) During the early Holocene, the rapid and early climate improvement is clearly shown by the expansion of warm-water adapted taxa, whilst persistence of cold-water adapted species may be related to climate instability and continentality. (iii) During the mid Holocene, the warm-water adapted taxa are correlated to the mid-Holocene climate optimum. (iv) From $6000 \mathrm{BP}$, the reappearance of many cold-water adapted taxa may have been induced by a slight global decline of summer temperatures.

Chironomids are therefore able to provide useful palaeoclimatic indications, especially in regions where continuous lacustrine sedimentary records are not available. This is especially the case for the French coastal plains of the North Sea where the Lateglacial and Holocene periods are poorly documented. Encouragingly, Brooks (2006) notes that fossil chironomids are now acknowledged as an essential component in most multiproxy palaeoenvironmental studies. However, further developments in Quaternary chironomid analysis, and especially the establishment of transfer functions adapted to river floodplain environments, require a better knowledge of modern ecological variables, such as thermal requirements and the geographical distribution of river taxa.

\section{Acknowledgements}

This study was funded by ANDRA. The BRGM provided logistical support for the coring. We are grateful to Dr Maria Rieradevall and Dr Stephen J. Brooks, who confirmed the identification of several subfossil larvae. We thank Dr N.J. Whitehouse and Dr P.G. Langdon for their corrections and valuable comments on this paper.

\section{References}

Allen, J.R.L. 2003: An eclectic morphostratigraphic model for the sedimentary response to Holocene sea-level rise in northwest Europe. Sedimentary Geology 161, 31-54.

Antoine, P., Lautridou, J.P. and Laurent, M. 2000: Long-term fluvial archives in NW France: response of the Seine and Somme rivers to tectonic movements, climatic variations and sea-level changes. Geomorphology 33, 183-207.

Atkinson, T.C., Briffa, K.R. and Coope, G.R. 1987: Seasonal temperatures in Britain during the last 22,000 years, reconstructed using beetle remains. Nature 325, 587-92.

Bard, E., Hamelin, B.J. and Fairbanks, R.G. 1990: U-Th ages obtained by mass spectrometry in corals from Barbados: sea level during the past 13,000 years. Nature 346, 456-58.

Bedford, A., Jones, R.T., Lang, B., Brooks, S.J. and Marshall, J.D. 2004: A late-glacial chironomid record from Hawes Water, northwest England. Journal of Quaternary Science 19, 281-90.

Behre, K.E. 2004: Coastal development, sea-level change and settlement history during the later Holocene in the Clay District of Lower Saxony (Niedersachsen), northern Germany. Quaternary International 112, 37-53.

Berendsen, H.J.A. and Stouthamer, E. 2000: Late Weichselian and Holocene palaeogeography of the Rhine-Meuse delta, The Netherlands. Palaeogeography, Palaeoclimatology, Palaeoecology $161,311-35$

Berger, A. and Loutre, M.F. 1991: Insolation values for the climate of the last 10 million years. Quaternary Science Reviews 10, 297-317. Bigler, C., Larocque, I., Peglar, S.M., Birks, H.J.B. and Hall, R.I. 2002: Holocene environmental change: a quantitative multi-proxy study from a small lake in Abisko, Swedish Lapland. The Holocene 12, 481-96.

Bigler, C., Grahn, E., Larocque, I., Jeziorski, A. and Hall, R. 2003 Holocene environmental change at Lake Njulla ( $999 \mathrm{~m}$ a.s.1.), northern Sweden, a comparison with four small nearby lakes along an altitudinal gradient. Journal of Paleolimnology 29, 13-29. 
Björck, J., Rundgren, M., Ingolfsson, O. and Funder, S. 1997: The Preboreal oscillation aroud the Nordic Seas: terrestrial and lacustrine responses. Journal of Quaternary Science 12, 455-65.

Björck, J., Andrén, T., Wastegard, S., Possnert, G. and Schoning, K. 2002: An event stratigraphy for the Last Glacial-Holocene transition in eastern middle Sweden: result from investigations of varved clay and terrestrial sequences. Quaternary Science Reviews 21, 1489-501.

Bogaart, P.W. 2003: Process-based modelling of the fluvial response to rapid climate change - with reference to the River Maas during the Last Glacial-Interglacial Transition. PhD thesis, Vrije Universiteit Amsterdam.

Bohncke, S.J.P. and Vandenberghe, J. 1991: Palaeohydrological development in the southern Netherlands during the last 15000 years. In Starkel, L., Gregory, K.J. and Thornes, J.B., editors, Temperate palaeohydrology. John Wiley and Sons Ltd, 254-81.

Bohncke, S., Vandenberghe, J., Coope, G.R. and Reiling, R. 1987: Geomorphology and palaeoecology of the Mark valley (southern Netherlands): palaeoecology, palaeohydrology and climate during the Weichselian Late Glacial. Boreas 16, 69-85.

Brodersen, K.P., Pedersen, O., Lindegaard, C. and Hamburger, K. 2004: Chironomids (Diptera) and oxy-regulatory capacity: an experimental approach to paleolimnological interpretation. Limnology and Oceanography 49, 1549-59.

Brooks, S.J. 2000: Late-glacial fossil midge stratigraphies (Insecta: Diptera: Chironomidae) from the Swiss Alps. Palaeogeography, Palaeoclimatology, Palaeoecology 159, 261-79.

— 2006: Fossil midges (Diptera: Chironomidae) as palaeoclimatic indicators for the Eurasian region. Quaternary Science Reviews 25, 1894-910.

Brooks, S.J. and Birks, H.J.B. 2000a: Chironomid-inferred lateglacial air temperatures at Whitrig Bog, south-east Scotland Journal of Quaternary Science 15, 759-64.

2000b: Chironomid-inferred late-glacial and early-Holocene mean July air temperatures for Krakenes Lake, Western Norway. Journal of Paleolimnology 23, 77-89.

Brooks, S.J., Mayle, F.E. and Lowe, J.J. 1997: Chironomid-based Lateglacial climatic reconstruction for southeast Scotland. Journal of Quaternary Science 12, 161-67.

Bryce, D. 1960: Studies of the larvae of the british Chironomidae (Diptera), with keys to the Chironominae and the Tanypodinae. Transaction of the Society for British Enthomology 14, 19-62.

Bryce, D. and Hobart, A. 1972: The biology and identification of the larvae of the Chironomidae (Diptera). Entomological Gazette 23, 175-217.

Bulankova, E., Halgos, J., Krno, I., Bitusik, P., Illesova, D., Lukas, J., Derka, T. and Sporka, F. 2001: The influence of different thermal regime on the structure of coenoses of stenothermal hydrobionts in mountain streams. Acta Zoologica Universitatis Comenianae 44, 95-102.

Clark, P.U., Marshall, S.J., Clarke, G.K.C., Hostetler, S.W., Licciardi, J.M. and Teller, J.T. 2001: Freshwater forcing of abrupt climate change during the last glaciation. Science 293, 283-87.

Coope, G.R. 1986: Coleoptera analysis. In Berglund, B.E., editor, Handbook of Holocene palaeoecology and palaeohydrology. Wiley \& Sons Ltd, 703-13.

1998: Part V. The biostratigraphy and palaeoecology. 4. Insects. In Preece, R.C. and Bridgland, D.R., editors, Late Quaternary environmental change in north-west Europe: excavations at Holywell Coombe, south-east England. Chapman \& Hall, 213-32. Coope, G.R. and Brophy, J.A. 1972: Late Glacial environmental changes indicated by a coleoptera succession from North Wales. Boreas 1, 97-142.

Coope, G.R. and Lemdahl, G. 1995: Regional differences in the Lateglacial climate of northern Europe based on coleopteran analysis. Journal of Quaternary Science 10, 391-96.

Cranston, P.S. 1982: A key to the larvae of the British Orthocladiinae (Chironomidae). Scientific Publications of the Freshwater Biological Association no. 45.

Davis, B.A.S., Brewer, S., Stevenson, A.C., Guiot, J. and Datacontributors 2003: The temperature of Europe during the Holocene reconstructed from pollen data. Quaternary Science Reviews 22, 1701-16.
Delettre, Y.R. 2005: Short-range spatial patterning of terrestrial Chironomidae (Insecta: Diptera) and farmland heterogeneity. Pedobiologia 49, 15-27.

Denys, L. and Baeteman, C. 1995: Holocene evolution of relative sea level and local mean high water spring tides in Belgium - a first assessment. Marine Geology 124, 1-19.

Dinnin, M. 1997: Holocene beetle assemblages from the Lower Trent floodplain ate Bole Ings, Nottinghamshire, U. K. Quaternary Proceedings 5, 83-104

Dubois, G. 1924: Recherches sur les terrains quaternaires du nord de la France. Mémoire de la Société Géologique du Nord.

Elias, S.A. 1994: Quaternary insects and their environments. Smithsonian Institution.

Ferrase, U. and Rossaro, B. 1981: Chironomidi, 1 (Diptera, Chironomidae: Generalità, Diamesinae, Prodiamesinae. Consiglio nazionale delle ricerche.

Fisher, T.G., Smith, D.G. and Andrews, J.E. 2002: Préboréal oscillation caused by a glacial Lake Agassiz flood. Quaternary Science Reviews 21, 873-78.

Francis, D.R. 2001: A record of hypolimnetic oxygen conditions in a temperate multi-depression lake from chemical evidence and chironomid remains. Journal of Paleolimnology 25, 351-65.

Gandouin, E. 2003: Enregistrement paléoclimatique interdisciplinaire de la transgression holocène. Signature paléoenvironnementale des Chironomidae (Diptères) du bassin de SaintOmer (France). $\mathrm{PhD}$ thesis, USTL.

Gandouin, E. and Franquet, E. 2002: Late glacial and Holocene chironomid assemblages in Lac Long Inférieur, south of France, $2090 \mathrm{~m}$. Palaeoenvironmental and palaeoclimatical implications. Journal of Paleolimnology 28, 317-28.

Gandouin, E., Franquet, E. and Van Vliet-Lanoë, B. 2005 Chironomids (Diptera) in river floodplains: their status and potential use for palaeoenvironmental reconstruction purposes. Archiv für Hydrobiologie 162, 511-34.

Gandouin, E., Maasri, A., Van Vliet-Lanoë, B. and Franquet, E. 2006: Chironomid (Insecta: Diptera) assemblages from a gradient of lotic and lentic waterbodies in river floodplains of France: a methodological tool for palaeoecological applications. Journal of Paleolimnology 35, 149-66.

Gehu, J.M. 1970: Carte de la végétation de la France. Lille no. 4 C.N.R.S

Grimm, E.C. 1987: Coniss: a fortran 77 program for stratigraphically constrained cluster analysis by the method of incremental sum of squares. Computers \& Geosciences 13, 13-35.

Guiot, J. and Couteaux, M. 1992: Quantitative climate reconstruction from pollen data in the Grand Duchy of Luxembourg since 15 000 yr BP. Journal of Quaternary Science 7, 303-309.

Haas, J.N., Richoz, I., Tinner, W. and Wick, L. 1998: Synchronous Holocene climatic oscillations recorded on the Swiss Plateau and at Timberline in the Alps. The Holocene 8, 301-309.

Hageman, B.P. 1969: Development of the western part of the Netherlands during the Holocene. Geologie en Mijnbouw 48, 373-88. Hammarlund, D., Barnekow, L., Birks, H.J.B., Buchardt, B. and Edwards, T.W.D. 2002: Holocene changes in atmospheric circulation recorded in the oxygen-isotope stratigraphy of lacustrine carbonates from northern Sweden. The Holocene 12, 339-51.

Heiri, O. and Lotter, A.F. 2003: 9000 years of chironomid assemblage dynamics in an Alpine lake: long term trends, sensitivity to disturbance, and resilience of the fauna. Journal of Paleolimnology $30,273-89$

Heiri, O., Lotter, A.F., Hausmann, S. and Kienast, F. 2003: A chironomid-based Holocene summer air temperature reconstruction from the Swiss Alps. The Holocene 13, 477-84.

Hofmann, W. 1984: Stratigraphie subfossiler Cladocera (Crustacea) und Chironomidae (Diptera) in zwei Sedimentprofilen des Meerfelder Maares. Courier Forschung-Institut Senckenberg 65, 67-80.

- 1986: Chironomid analysis. In Berglund, B.E., editor, Handbook of Holocene palaeoecology and palaeohydrology. Wiley \& Sons Ltd. 715-27.

1998: Cladocerans and chironomids as indicators of lake level changes in north temperate lakes. Journal of Paleolimnology 19 , $55-62$. 
Hofmann, W. and Winn, K. 2000: The Littorina transgression in the western Baltic Sea as indicated by subfossil Chironomidae (Diptera) and Cladocera (Crustacea). International Review of Hydrobiology 85, 267-91.

Huisink, M. 2000: Changing river styles in response to Weichselian climate changes in the Vecht valley, eastern Netherlands. Sedimentary Geology 133, 115-34.

Huntley, B. and Prentice, I.C. 1988: July temperatures in Europe from pollen data, 6000 years before present. Science 241, 687-90.

Isarin, R.F.B. and Bohncke, S.J.P. 1999: Mean July temperatures during the Younger Dryas in northwestern and central Europe as inferred from climate indicator plant species. Quaternary Research 51, 158-73.

Isarin, R.F.B., Renssen, H. and Vandenberghe, J. 1998: The impact of the North Atlantic Ocean on the Younger Dryas climate in northwestern and central Europe. Journal of Quaternary Science $13,447-53$.

Kiden, P. 1995: Holocene relative sea-level change and crustal movement in the southwestern Netherlands. Marine Geology 124, 21-41.

Korhola, A., Olander, H. and Blom, T. 2000: Cladoceran and chironomid assemblages as quantitative indicators of water depth in subarctic Fennoscandian lakes. Journal of Paleolimnology 24, 43-54.

Korhola, A., Vasko, K., Toivonen, H.T.T. and Olander, H. 2002: Holocene temperature changes in northern Fennoscandia reconstructed from chironomids using Bayesian modelling. Quaternary Science Reviews 21, 1841-60.

Lambeck, K. 1997: Sea-level change along the French Atlantic and Channel coasts since the time of the Last Glacial Maximum. Palaeogeography, Palaeoclimatology, Palaeoecology 129, 1-22.

Langdon, P.G., Ruiz, Z., Brodersen, K.P. and Foster, I.D.L. 2006: Assessing lake eutrophication using chironomids: understanding the nature of community response in different lake types. Freshwater Biology 51, 562-77.

Larocque, I., Hall, R.I. and Grahn, E. 2001: Chironomids as indicators of climate change: a 100-lake training set from a subarctic region of northern Sweden (Lapland). Journal of Paleolimnology $26,307-22$

Limondin, N. and Rousseau, D.D. 1991: Holocene climatic variations recorded by malacofaunas at Verrières (Seine Valley, France) Compte Rendu de l'Académie des Sciences (IIa) 313, 215-21.

Long, A.J., Innes, J.B., Kirby, J.R., Lloyd, J.M., Rutherford, M.M., Shennan, I. and Tooley, M.J. 1998: Holocene sea-level change and coastal evolution in the Humber estuary, eastern England: an assessment of rapid coastal change. The Holocene 8 , $229-47$.

Long, A.J., Plater, A.J., Waller, M.P. and Innes, J.B. 1996: Holocene coastal sedimentation in the Eastern English Channel new data from the Romney Marsh region, United Kingdom. Marine Geology 136, 97-120.

Lotter, A.F., Birks, H.J.B., Hofmann, W. and Marchetto, A. 1997 Modern diatom, cladocera, chironomid, and chrysophyte cyst assemblages as quantitative indicators for the reconstruction of past environmental conditions in the Alps. I. Climate. Journal of Paleolimnology 19, 395-420.

Lotter, A.F., Birks, H.J.B., Hofmann, W. and Marchetto, A. 1998: Modern diatom, cladocera, chironomid, and chrysophyte cyst assemblages as quantitative indicators for the reconstruction of past environmental conditions in the Alps. II. Nutrients. Journal of Paleolimnology 19, 443-63.

Lowe, J.J. and Walker, M.J.C. 1997: Reconstructing Quaternary environments, second edition. Prentice Hall.

Magny, M. 2001: Palaeohydrological changes as reflected by lakelevel fluctuations in the Swiss Plateau, the Jura Mountains and the northern French Pre-Alps during the Last Glacial-Holocene transition: a regional synthesis. Global and Planetary Change 30, 85-101.

2004: Holocene climate variability as reflected by mid-European lake-level fluctuations and its probable impact on prehistoric human settlements. Quaternary International 113, 65-79.

Magny, M., Guiot, J. and Schoellammer, P. 2001: Quatitative reconstruction of Younger Dryas to mid-Holocene paleoclimates at Le Locle, Swiss Jura, using pollen and lake-level data. Quaternary Research 56, 170-80.
Magny, M., Bégeot, C., Guiot, J. and Peyron, O. 2003: Contrasting patterns of hydrological changes in Europe in response to Holocene climate cooling phases. Quaternary Science Reviews 22, 1589-96.

Mandaville, S.M. 2002: Benthic macroinvertebrates in freshwaters taxa tolerance values, metrics, and protocols. Retrieved 15 January 2007 from http://lakes.chebucto.org/H-1/tolerance.pdf

Mansy, J.L., Manby, G.M., Averbuch, O., Everearts, M., Bergerat, F., Van Vliet-Lanoë, B., Lamarche, J. and Vandycke, S. 2003 Dynamics and inversion of the Mesozoïc Basin of the WealdBoulonnais area: role of basement reactivation. Tectonophysics 373, 161-79.

Mayewski, P.A., Rholing, E.E., Stager, J.C., Karlen, W., Maasch, K.A., Meeker, L.D., Meyerson, E.A., Gasse, F., Van Kreveld, S., Holmgren, K., Lee-Thorp, J., Rosqvist, G., Rack, F., Staubwasser, M., Schneider, R.R. and Steig, J.E. 2004: Holocene climate variability. Quaternary Research 62, 243-55.

Millet, L. 2004: Les assemblages de Chironomidae, marqueurs des changements de l'environnement et du climat pendant le Pléniglaciaire et le Tardiglaciaire. Etude de trois séquences lacustres d'Allemagne, du Jura et de Toscane. PhD thesis, Université de Franche-Comté

Mousavi, S.K. 2002: Boreal chironomid communities and their relations to environmental factors - the impact of lake depth, size and acidity. Boreal Environnment Research 7, 63-75.

Mullenders, W., Desair-Coremans, M. and Gilot, E. 1972 Recherches palynologiques et datations $14 \mathrm{C}$ sur les dépôts tourbeux de Holsbeek. Archeologia Belgica 138, 133-42.

Munaut, A.-V. and Paulissen, E. 1973: Evolution et paléo-écologie de la vallée de la petite Nèthe au cours du Post-Würm (Belgique). Annales de la Société Géologique de Belgique 96, 301-48.

Olander, H., Birks, H.J.B., Korhola, A. and Blom, T. 1999: An expanded calibration model for inferring lakewater and air temperatures from fossil chironomid assemblages in northern Fennoscandia. The Holocene 9, 279-94.

Oliver, D.R. and Dillon, M.E. 1997: Chironomids (Diptera: Chironomidae) of the Yukon Artic North Slope and Herschel Island. In Danks, H.V. and Downes, J.A., editors, Insects of the Yukon. Biological Survey of Canada (Terrestrial Arthropods), 615-25.

Pinder, L.C.V. 1995: The habitats of chironomid larvae. In Armitage, P.D., Cranston, P.S. and Pinder, L.C.V., editors, The Chironomidae. Biology and ecology of non-biting midges. Chapman \& Hall, 107-35.

Pirazzoli, P.A. 1991: World atlas of Holocene sea-level changes. Elsevier Science Publishers BV.

Plater, A.J., Ridgway, J., Rayner, B., Shennan, I., Horton, B.P., Haworth, E.Y., Wright, M.R., Rutherford, M.M. and Wintle, A.G. 2000: Sediment provenance and flux in the Tees Estuary: the record from the Late Devensian to the present. In Shennan, I. and Andrews, J.E., editors, Holocene land-ocean interaction and environmental change around the North Sea. Geological Society Special Publication, 171-95.

Ponel, P., Coope, G.R., Antoine, P., Limondin-Lozouet, N. Leroyer, C., Munaut, A.-V., Pastre, J.F. and Guiter, F. 2005: Lateglacial palaeoenvironments and palaeoclimates from Conty and Houdancourt, Northern France, reconstructed from Beetle remains. Quaternary Science Reviews 24, 2449-65.

Preece, R.C. 1995: Island Britain: a Quaternary perspective. Geological Society Special Publication.

Preece, R.C. and Bridgland, D.R. 1999: Holywell Coombe, Folkestone: a 13,000 year history of an English Chalkland Valley. Quaternary Science Reviews 18, 1075-125.

Quinlan, R. and Smol, J.P. 2001a: Chironomid-based inference models for estimating end-of-summer hypolimnetic oxygen from south-central Ontario shield lakes. Freshwater Biology 46, 1529-51. 2001b: Setting minimum head capsule abundance and taxa deletion criteria in chironomid-based inference models. Journal of Paleolimnology 26, 327-42.

Ran, E.T.H. 1990: Dynamics of vegetation and environment during the middle pleniglacial in the Dinkel valley (the Netherlands). Mededelingen Rijks Geologische Dienst 44, 141-205.

Renssen, H. and Isarin, R.F.B. 2001: The two major warming phases of the last deglaciation at $\sim 14.7$ and $\sim 11.5 \mathrm{ka}$ cal BP in Eu- 
rope: climate reconstructions and AGCM experiments. Global and Planetary Change 30, 117-53.

Rieradevall, M. and Brooks, S.J. 2001: An identification guide to subfossil Tanypodinae larvae (Insecta: Diptera: Chironomidae) based on cephalic setation. Journal of Paleolimnology 25, 81-99.

Rosén, P., Segerström, U., Eriksson, L., Renberg, I. and Birks, H.J.B. 2001: Holocene climatic change reconstructed from diatoms, chironomids, pollen and near-infrared spectroscopy at an alpine lake (Sjuodjijaure) in northern Sweden. The Holocene 11, 551-62.

Rosén, P., Segerström, U., Eriksson, L. and Renberg, I. 2003: Do diatom, chironomid, and pollen records consistently infer Holocene July air temperature? A comparison using sediment cores from four alpine lakes in northern Sweden. Arctic, Antarctic and Alpine Research 35, 279-90.

Rossaro, B. 1982: Chironomidi, 2 (Diptera Chironomidae: Orthocladiinae). Consiglio Nazionale delle Ricerche. 87-98.

Chironomid and water temperature. Aquatic Insects 13

Rossaro, B., Lencioni, V., Boggero, A. and Marziali, L. 2006 Chironomids from Italian Alpine running waters: taxonomy, ecology, biogeography. Hydrobiologia 562, 231-46.

Ruiz, Z., Brown, A.G. and Langdon, P.G. 2006: The potential of chironomid (Insecta: Diptera) larvae in archaeological investigations of floodplain and lake settlements. Journal of Archaeological Science 33, 14-33.

Sadler, J.P. and Jones, J.C. 1997: Chironomids as indicators of Holocene environmental changes in the British Isles. Quaternary Proceedings 5, 219-32.

Schmid, P.E. 1993: A key to the larval chironomidae and there instars from austrian danube region streams and rivers. Federal Institute for Water Quality.

Scourse, J.D. and Austin, R.M. 1995: Palaeotidal modelling of continental shelves: marine implications of a land-bridge in the Strait of Dover during the Holocene and Middle Pleistocene. In Preece, R.C., editor, Island Britain: a Quaternary perspective. Geological Society Special Publication, 75-88

Serra-Tosio, B. and Laville, H. 1991: Liste annotée des Diptères Chironomidés de France Continentale et de Corse. Annales de Limnologie 27, 37-74.

Shennan, I. and Andrews, J.E. 2000: Holocene land-ocean interaction and environmental change around the North Sea. Geological Society, Special Publication.

Shennan, I., Lambeck, K., Flather, R., Horton, B., McArthur, J., Innes, J., Lloyd, J., Rutherford, M. and Wingfield, R. 2000: Modelling western North Sea palaeogeographies and tidal changes during the Holocene. In Shennan, I. and Andrews, J.E., editors, Holocene land-ocean interaction and environmental change around the North Sea. Geological Society Special Publication, 299-319.

Sommé, J., Munaut, A.V., Emontspohl, A.F., Limondin, N., Lefèvre, D., Cunat-Bogé, N., Mouthon, J. and Gilot, E. 1994: The Watten boring - an Early Weichselian and Holocene climatic and palaeoecological record from the French North Sea coastal plain. Boreas 23, 231-43.

Starkel, L. 1991: Environmental changes at the Younger Dryas-Preboreal transition and during the early Holocene: some distinctive aspects in central Europe. The Holocene 1, $234-42$.

Streif, H. 2004: Sedimentary record of Pleistocene and Holocene marine inundations along the North Sea coast of Lower Saxony, Germany. Quaternary International 112, 3-28.

Stribling, J.B., Jessup, B.K., White, J.S., Boward, D. and Hurd, M. 1998: Development of a benthic index of biotic integrity for Maryland streams. Maryland Department of Natural Resources. Retrieved 25 January 2007 from http://www.dnr.state.md.us/ streams/pubs/1998_benthic_ibi.pdf
Stuiver, M., Reimer, P.J., Bard, E., Beck, J.W., Burr, G.S., Hughen, K.A., Kromer, B., McCormac, G., van der Plicht, J. and Spurk, M. 1998: INTCAL98 radiocarbon age calibration, 24,000 to 0 cal BP. Radiocarbon 40, 1041-83.

Teller, J.T., Leverington, D.W. and Mann, J.D. 2002: Freshwater outburst to the oceans from glacial Lake Agassiz and their role in climate change during the last deglaciation. Quaternary Science Reviews 21, 879-87.

Thioulouse, J., Chessel, D., Dolédec, S. and Olivier, J.M. 1997 ADE-4: a multivariate analysis and graphical display software Statistics and Computing 7, 75-83.

Tourenq, J.N. 1975: Recherches écologiques sur les Chironomides (Diptera) de Camargue. Thèse doctorat d'état thesis, University of Toulouse.

Tukey, J. 1977: Exploratory data analysis. Addison-Wesley.

Van der Woude, J.D. and Roeleveld, W. 1985: Paleoecological evolution of an interior coastal zone: the case of the northern France coastal plain. Bulletin de l'Association française pour l'étude du Quaternaire 1, 31-39.

Van Geel, B., Coope, G.R. and Van der Hammen, T. 1989: Palaeoecology and stratigraphy of the Lateglacial type section at Usselo (the Netherlands). Review of Palaeobotany and Palynology 60 , $25-129$.

Van Vliet-Lanoë, B., Gandouin, E. and Meurisse, M. 2004: Évolution des niveaux marins quaternaires dans le Nord de la France: données nouvelles et mise au point. Sucellus 55, 1-16.

Van Zeist, W. and Van der Spoel-Walvius, M.R. 1980: A palynological study of the Late-Glacial and the Postglacial in the Paris Basin. Palaeohistoria 22, 68-109.

Velle, G., Brooks, S.J., Birks, H.J.B. and Willassen, E. 2005 Chironomids as a tool for inferring Holocene climate, an assessment based on six sites in southern Scandinavia. Quaternary Science Reviews 24, 1429-62.

Walker, I.R. and Mathewes, R.W. 1989: Chironomidae (Diptera) remains in surficial lake sediments from the Canadian Cordillera: analysis of the fauna across an altitudinal gradient. Journal of Paleolimnology 2, 61-80.

Walker, I.R., Levesque, A.J., Cwynar, L.C. and Lotter, A.F. 1997: An expanded surface-water palaeotemperature inference model for use with fossil midges from eastern Canada. Journal of Paleolimnology 18, 165-78.

Walker, M.J.C., Bohncke, S., Coope, G.R., O'Connel, M., Usinger, H. and Verbruggen, C. 1994: The Devensian/Weichselian LateGlacial in northwest Europe (Ireland, Britain, north Belgium, The Netherlands, northwest Germany). Journal of Quaternary Science 9 109-18.

Waller, M.P. 1994: Flandrian vegetational history of south-eastern England. Stratigraphy of the Brede valley and pollen data from Brede Bridge. New Phytologist 126, 369-92.

Waller, M.P. and Long, A.J. 2003: Holocene coastal evolution and sea-level change on the southern coast of England: a review. Journal of Quaternary Science 18, 351-59.

Wiederholm, T. 1983: Chironomidae of the Holarctic region. Keys and diagnoses. Part I: larvae. Entomologica Scandinavica Supplement.

Wonnacott, T.H. and Wonnacott, R.J. 1990: Introductory statistics for business and economics. Wiley.

Ybert, J.P., Bissa, W.M., Catharino, E.L.M. and Kutner, M. 2003 Environmental and sea-level variations on the southeastern Brazilian coast during the Late Holocene with comments on prehistoric human occupation. Palaeogeography, Palaeoclimatology, Palaeoecology 189, 11-24.

Zagwijn, W.H. 1994: Reconstruction of climate change during the Holocene in western and central Europe based on pollen records of indicator species. Vegetation History and Archaeobotany 3, 65-88. 